\title{
Dynamic Self-Organizing Social and Cultural Processes in Global Development of Humanity in Terms of Synergetic Historicism
}

\author{
Irina Gennadievna Mikailova ${ }^{1}$, Maria Romanovna Zobova ${ }^{2}$ \\ ${ }^{1}$ Department of Philosophy of Science and Technologies, St. Petersburg Humanitarian Centre for Education and Development, St. \\ Petersburg, Russia \\ ${ }^{2}$ Department of Philosophy, St. Petersburg State University of Telecommunications, St. Petersburg, Russia
}

\section{Email address:}

imikailoff@inbox.lv (I. G. Mikailova),swbussoff@mail.ru (M. R. Zobova)

\section{To cite this article:}

Irina Gennadievna Mikailova, Maria Romanovna Zobova. Dynamic Self-Organizing Social and Cultural Processes in Global Development of Humanity in Terms of Synergetic Historicism. International Journal of Philosophy. Vol. 6, No. 3, 2018, pp. 84-106.

doi: $10.11648 /$ j.ijp.20180603.14

Received: October 3, 2018; Accepted: October 29, 2018; Published: November 26, 2018

\begin{abstract}
The article, Dynamic Self-Organizing Social and Cultural Processes in Global Development of Humanity in Terms of Synergetic Historicism, is focused on discussing a new methodological approach to the study on specific regularities of global development of humanity from the Synergetic Philosophy of History perspective. Such an approach to the speculation on interconnected problems both of human origins in the Universe and mankind's global future allows to be concentrated on self-organizing interconversions between poles of the cardinal dual opposition of Order and Chaos. The investigation in question is based on such a progressive methodology as the Law of Self- Organizing Social, Cultural, and Religious Ideals, as well as the Method of Dual Oppositions. The Law of Self-Organizing Ideals contributes to overcome a vicious Utopian Circle and obtain identity between the absolute ideal common to all mankind and individual ideals of every member of society, according to the principle of self-similarity of dissipative systems. Substantiating rationality of the universal spiral pattern in the Universe from the Synergetic Historicism Viewpoint assists in considering life as a well-balanced system of both biological and sociological aspects. However, disturbing this balance results in both negation of life and selfdestruction of a system itself. Considering Self-expressing Subjects called "Homo Faber" as a kind of ideological as well as social and political "animals" permits to demonstrate that any idealization is inherent in human beings' mental activity only, since the only society is characterized by reproducing ideals and values. The methodological base created by the authors, is oriented not only towards grounding the inevitability of transforming "Homo Sapiens" as biological animals into "Homo Faber" as ideological animals in the first stage, as well as of transforming "Homo Faber" into "Homo Super", in the second stage of global development. Such a transformation assists not only in overwhelming barriers of evolution processes, intruded on by natural laws, but also in investigating the most important theoretical prerequisites of synthesizing social and cultural as well as Scientific and Technological progress. Revealing interrelationships between the problem of a sense of social history and the meaning-of-life of society members allows to substantiate specific regularities of reproducing the genetic code and its transforming into the ideological code in a transitional stage from synthesizing Social and Cultural as well as Scientific and Technological Progress to a self-organizing Superhuman society.
\end{abstract}

Keywords: Law of Self-Organizing Ideals, Dual Oppositions, Social and Cultural Progress, Global Development, Scientific and Technological Progress, Ideological Code, Anthropic Principles, Cosmological Model 


\section{A Synergistic Approach to the Study on Regularities of Global Development of Humanity}

In the course of complicating dynamic social and cultural processes with their transformations, the study on mechanisms of social and cultural transformations, on the one hand, and on regularities of global development of humanity, on the other, based on the Law of Self-organizing social, cultural, and religious ideals as well as on the Method of Dual Oppositions, became more and more actualized. Such investigations aimed at a criticism of limitedness of historical experience and actualizing a dramatic sense of realizing society members needs for speculating on problems of synthesis of scientific and humanitarian thinking as well as consequences of Scientific and Technological Progress, contribute to finding a solution to problems in question [1].

Globalization, considered according to the Synergetic Historicism conception as a new phenomenon of social life opposed by deglobalization, is thought of as a way to global human mentality achieved through a potentially local diversity. This concept is evidently exemplified by a bifurcation of global progress which demonstrates a constructive-cum-destructive role of Chaos.

The conception of Synergetic Historicism is based on the notion of self-organization allowing to take into account ontological, gnoseological, and axiological aspects. This specific nature of self-organization is determined by three interrelated vectors:

(1) firstly, by self-organizing objective reality as an aggregate of material objects existing in nature independent of man;

(2) secondly, by self-organizing subjective reality as the aggregate of human knowledge concerning real and imagined objects;

(3) and thirdly, by self-organizing subjective and objective reality as the aggregate of artefacts embodying human knowledge and satisfying human requirements.

And, inasmuch as self-organization is characterized by alternating polar processes, generating Order from Chaos, on the one hand, and Chaos from Order, on the other, the problem of their intertransitions becomes the dominant in the History of Philosophy [2].

Moreover, thinking of many other philosophical issues is based on studying those interpretations evidenced by the history of world culture from the nineteenth to twentieth centuries [3].

The results of the detailed analysis of the historical panorama of events in the twentieth century allowed to substantiate that global development of humanity originates in its global self-organization. And besides, a solution to the problem of self-organization is equated with the law governing humanity. Opposite conceptions of the ideological totalitarian, or closed society, similar to the world-wide dictatorship of Proletariat contrived by Karl Marx (18181883 ) and Friedrich Engels (1820-1895), and the consumer anarchist, or open society, proclaimed by Sir Karl Raimund Popper (1902-1994), clearly illustrate two approaches to this problem. So then, the conception of ideological totalitarian society, based on a cult of order and responsibility and aimed at a totalitarian ideal determining a totalitarian statehood model, contravenes the conception of consumer society, based on a cult of absolute freedom and aimed at a utilitarian anarchist ideal, in the wake of striving after both Totalitarianism and Anarchism. Due to a paradox resulting from such a collision, the outcome of this struggle becomes unpredictable.

An advantage of the approach to a problem of chaos-toorder and order- to-chaos transitions proposed from the Synergetic Historicism ${ }^{1}$ perspective, over other known approaches, consists in rethinking the traditional primacy of one of those reality conditions [4] in favour of interrelations of attraction and repulsion. The synergistic approach to the problem of global development of humanity allows to consider the future as a material embodiment of the absolute ideal common to all mankind, established in the course of the struggle between relative individual ideals for their dominant role in a society in the world history. Such a struggle results not only in destroying non-invariant aspects of individual ideals but also in isolating invariant, never changing aspects synthesized in the ideal common to all mankind. Such a process shows the constructive role of ideological chaos, confirming that global development of humanity is characterized by processes of forming and realizing the ideal common to all mankind. Therefore, the general theory of ideals and ideology considered to be the teaching on ideals, is a fundamental core of Synergetic Philosophy of History [5].

However, the theory of ideals is to be distinguished from the so-called scientific ideology due to the cardinal differences between science and the teaching on truth and ideology as the teaching on ideals. Nevertheless, this fundamental philosophic problem of interrelationship between truth and ideal in terms of general theory of selforganization, for a longtime escaped researchers' notice, who erroneously identified the notion of True with that of Ideal.

Thereby, the Synergetic Historicism conception allows not only to focus researchers' attention on interrelationship between both notions, determined by initial principles of philosophical Weltanschauung, but also to consider regularities of theory formation in terms of a developed philosophical system.

Indeed, science as the teaching on truth and ideology as the teaching on ideals might have been identified on condition that both notions would also have been identified (but they are not) [6]. And, if the truth implies the correspondence of knowledge to reality, the ideal means the correspondence of knowledge to human wish to see reality

\footnotetext{
1 Synergetics is regarded as interdisciplinary science aimed at explaining the formation and self-organization of patterns and structures in open systems far from thermodynamic equilibrium, founded by Hermann Haken (b.1927), the German physicist. Haken's interpretation of the laser principles as selforganization of non-equilibrium systems resulted in the late 1960s in developing Synergetics.
} 
being transformed in accordance with this wish. In contradistinction to the truth adequately reflecting objective reality, the ideal transforms this reality, and reflects the correspondence of knowledge to reality transformed in accordance with human wishes and based on faith and sacrifice [7].

Dramatic nuances inherent to the problem of interrelation between science and ideology may be explained by a struggle between two opposite ideologies, the totalitarian and the liberal. Karl Marx and Friedrich Engels in their early works identified "ideology" with "false consciousness", whereas in their later works, the communist ideology was proclaimed by them the only true one. Their view on ideology was shared by Vladimir Lenin (Vladimir I. Ulyanov / 1870-1924) in his work 'Materialism and Empiriocriticism' (1908). However, the synergistic approach prevents from considering any knowledge as 'true' or 'false' because such a classification is applied neither to pragmatic program knowledge nor to utopian knowledge.

Synergetic Historicism, teaching that the notions of 'Truth' and 'Ideal', on the one hand, and those of 'Science' and 'Ideology', on the other, are not equated, substantiates the notion of the scientific theory of ideology as expedient, whereas that of scientific ideology as erroneous [8].

\section{The Synergetic Model of Global Development of Humanity}

The Model of Global Progress built up by the authors from the Synergetic Historicism position is based on the Law of Self-organizing social, cultural, and religious ideals. ${ }^{2}$ This Law proclaims that the ideal common to all mankind as the fundamental invariant of any ideology is to be established as to provide a potentially infinite movement of humanity to the Global Attractor. This Global Attractor (also called the Superattractor $)^{3}$ is considered to be a materially embodied intersubjective (that is to say, existing between many conscious minds) ideal common to all mankind. The notion of the movement to this Global Attractor, incorporated into the Synergetic Historicism conception, allows to ground a genuine sense of social history and the development of world culture, on the one hand, and that of individual subsistence and death, on the other. ${ }^{4}$

The particular significance of this innovative Global

2 The Law of Self-organizing ideals governs processes of their differentiation, integration, desintegration, and synthesis [9].

3 The innovative Global Attractor concept differs from the notion of the Great Attractor, which, as an apparent gravitational anomaly in intergalactic space at the centre of the Laniakea Supercluster, is moving towards the Shapley Supercluster. 4 Synergetic Historicism conception regards individual subsistence, freedom, and choice as three main products of conscious human minds, being capable of defining their own meaning-of-life and trying to make rational decisions despite existing in an irrational universe. And besides, from the Synergetic Historicism viewpoint, the notion of the meaning-of-life is related to the circle of questions as follows: firstly, what have humans appeared in the Universe for? Secondly, what is the sense to live and die? Thirdly, what is the purpose of life and death? Fourthly, are humans in need of obtaining immortality? And, finally, if humans would have become immortal, would not their life have been devaluated? [10].
Attractor concept consists in its embracing all the fields of social, cultural and religious life of humanity whose representatives are orientated by it towards transformation into Superhumanity. The potentially infinite movement of social, cultural, and religious systems to this Global Attractor is determined by the Principles of Self-organization and Social and Cultural Selection. Opting for the only alternative from multitude found in the Thesaurus, takes place on obtaining a multifurcation point. The principle of interconnected social and cultural systems' constituents being a factor of social and cultural evolution, by the agency of which this choice is taken, we call the Detector. This Detector is controlled by the maximum stability factor, called the Selector. The movement of social and cultural systems to the Universal Order of all things and to Differential Chaos is determined by the Global Selection process, imparting to this movement its asymptotic character and allowing to resist a threat of impending global crisis. Thus, the main sense of social advancement consists in the strategy of foreseeing and preventing such a global crisis.

The special significance of Global Social Progress is determined by the organizing role of the Global Attractor. Therefore, from the Synergetic Historicism viewpoint, the teaching on Global Social Progress promotes the idea of the Global Attractor as the synthesis of Social, Cultural, Scientific and Technological Progress, on the one hand, and as the apogee of harmonious Superhuman civilization, on the other. Self-organizing processes are considered by the authors as Creative Order-to- constructive Chaos transition within the system of cardinal dual oppositions between simple and strange attractors, which not only provide dynamical transitions between their two poles, but also assist in potentially infinite approaching the Global Attractor. The Global Selection, ensuring this potentially infinite approaching the Global Ideal, determines the constructive aspect of the simple selection, which creates a new Thesaurus. In this way, a quantitatively new stage of Constructive Chaos is initiated, transforming both the Detector and Selector as to assist in obtaining a measure of synthesis of Chaos and Order as well as to ensure maximum stability of a system.

The Synergetic Historicism conception, having put forward a qualitatively new approach to the speculation on the fundamental problem of interrelations between ideals and ethical norms declared by them, has also substantiated an issue of natural (not transcendental) sources of generating ethics. And if the natural source of generating ethical canons originates in objective reality, the transcendental one, in turn, originates in intersubjective ideals. This fact explains differences and similarities in ethical canons. The absolute truth common to all mankind is formed in the wake of disintegration and synthesis of potentially infinite multitudes of relative individual truths, whereas the absolute ideal common to all mankind is formed owing to disintegration and synthesis of potentially infinite multitudes of relative individual ideals. Moreover, those parallel processes are interrelated, since the reproduction of pragmatic aspects of 
any ideal requires knowledge of certain truths [11].

The authors of "The Global Future 2045" [12] ascribe to global curve of evolution a hyperbolic character, whereas the authors of "The Global Future, Transhumanism, and Synergetic Philosophy of History" [13] impart to the Global Law of Self-organization qualities of an universal spiral. This spiral combines reversibility of qualitative transformations in the Universe with that of new formations [14].

The authors of both conceptions associate Global Selforganization with a notion of singularity. ${ }^{5}$ However, if the former conception considers the singularity as one of bifurcation local points, resulting either in destroying a selforganizing system or in the transition to a qualitatively other state, the later regards the singularity as the Global Attractor, characterized by such a state of a self-organizing system which all local, simple, and strange attractors strive for, and which provides maximum stability of a system [15].

The Emotional Model of Social Self-organization contrived by the authors of the later conception from the Synergetic Philosophy of History position, is based on the results of analysis of self-organizing states and their emotional reflexion in rational notions on the base of the Law of Self-organizing social, cultural, and religious ideals. And, inasmuch as this law takes into account not only a heyday of ideals but also their destruction, evolution of ideals generates both positive (owing to a struggle for ideals and their triumph) and negative (owing to a struggle for ideals and their defeat) emotions. Nevertheless, human morality is manifested in forms such as "Red Revolutionary Optimism", "Pink Secular Optimism" or "Bloody Black Pessimism" of the alarmist ideology, generating the insuperable fear of the future of Humanity [16].

The Emotional Model of Social Self-organization might be submitted in a form of panorama of permanently alternating ideals and values proclaimed by them, according to the Law of Self-organizing social, cultural, and religious ideals, in the course of the potentially infinite movement of Humanity to the Global Attractor, regarded by the authors as the global limit of self-organization. This global limit is characterized by achieving the measure of synthesis (considered to be a counter-balancing point) between the striving of humanity for a cult of one-sided Freedom (leading to anarchical Chaos achieved through violating social norms), on the one hand, and the striving for a cult of one-sided Responsibility (leading to totalitarian Order achieved through thrusting social norms), on the other [17].

Any attempts to hinder a process of alternating social and cultural ideals by means of artificial intensifying vectors of one-sided striving either after Freedom (resulting in Chaos) or after Responsibility (resulting in Order) in a long-term perspective inevitably undergo counter-fluctuations,

\footnotetext{
5 The singularity is the hypothesis that the invention of artificial superintelligence will result not only in abrupt technological growth but also in unfathomably transformation of human civilization into Superhumanity [19]. This hypothesis describes the process of transforming each new and more intelligent generation, causing an intelligence explosion, into a powerful superintelligence qualitatively far surpassing all human intelligence [20].
}

providing a system with maximum stability. In this manner, the movement to the Global Attractor does not depend on a level of its cognition. Therefore, a success of any long-term prognosis depends on whether the social law would become a statute self-regulatory organization, taking into account both a constructive and destructive role of Chaos. 'Non-linear' character of synergetic thinking is thus revealed in intertransitions from positive emotions to negative ones and vice versa, on the one hand, and in recurrent tiredness of negative emotions, on the other. This non-linearity, according to the Law of Self-organizing ideals, assists in providing humanity with a stable dominant of positive emotions of socalled "Dramatic Optimism" in a long-term perspective [18].

Social (or interpersonal) Freedom provided by controlling natural selection ${ }^{6}$ (as a key mechanism of evolution) by means of modelling social production and reproduction, is regarded as the superstructure over biological life. The Social Selection ${ }^{7}$ quality is determined by subjective factors, in turn, determining any constructive or destructive way of historical development. Any choice taken in any stage of social and cultural evolution, leads to Global Selection. However, the adequacy of this option is determined by subjective factors, to wit, by the extent of its conformity to relative individual ideals shared by subjects of choice. Thus, subjects have no option but that corresponding to their own ideals. Nevertheless, objective factors of option are aimed at the absolute ideal common to all mankind, resulting in lacking conformity to the choice taken on the basis of relative individual ideals, as well as to the way of social and cultural evolution determined by the absolute ideal common to all Humanity and Superhumanity. The option for a constructive way of Self-determination is always aimed at the absolute ideal, whereas the option for a destructive way aimed at antiideals and anti-values, always resulting in self-destroying subjects of choice [23].

Any large society (or any state) possessing its established infrastructure, should be aimed not only at satisfying its members' necessaries of life, but also at developing their capabilities of achieving the measure of synthesis of Freedom and Responsibility in order to provide themselves with the option ensured by their Constitution. Freedom of choice, however, is frequently replaced with an ideological strategy, allowing to shift the vector of self-organization from a stance, corresponding to the meaning of society members' life, to a stance aimed at realizing social and political ambitions by oligarchic governments. Nevertheless, lessons taken from global history, show that a key to the successful reproduction of any polity model is always the factor of

6 Natural selection is the differential survival and reproduction of individuals due to differences in phenotype, the change in the heritable traits of a population over generations. The theory of natural selection was conceived by Charles Robert Darwin (1809-1882), the English naturalist and biologist, in 1838 [21].

7 Social selection is a mode of natural selection based on reproductive transactions and a two-tiered approach to evolution and the development of social behaviour. The theory of social selection was conceived by Joan Roughgarden (b. 1946), the American ecologist and evolutionary biologist, as an alternative to sexual selection [22] 
subjecting society members behavioural and moral patterns to a commonly significant dominant ideal which, in turn, stipulates state ideological and political programs [24].

Thereby, Friedrich Engels considered "die List der Vernunft (the Cunning of Reason) des Weltgeistes" (of World Spirit) [25], contrived by Georg Wilhelm Friedrich Hegel (1770-1831) as "das Parallelogram der Willen und Wünschen" (the Parallelogramm of Intentions and Wishes), bringing about not only unforeseen but also unwanted trends of historical events. Friedrich Engels regarded such a phenomenon as a frightening paradox rooted in the key problem of Freedom of choice.

The results of analyzing specific regulations on social selection (as well as on superselection) from the Synergetic Historicism viewpoint assisted in eliminating such a paradox. And although any society controlling its own history, would have been called Utopian, on the contrary, any society being capable of founding trends in its own social and cultural progress, seems to us to be quite real.

Obtaining the measure of synthesis of Freedom and Responsibility is a key to the successful tracing stochastically self-organizing social and cultural processes, tending to increase the complexity of social and cultural evolution. However, treating the notion of Responsibility as a pole opposed to a pole of Freedom, limited by an Ethical Canon [26], results in reducing this important philosophical category to the ethical one, thus bowdlerizing its ontological significance.

Rethinking G. W. F. Hegel's approach to the creative function of World Spirit (Spiritus mundi / der Weltgeist), aimed at achieving Creative Order and Social and Cultural Progress through reification (die Verdinglichung), historicization and hierarchization, as well as through considering Freedom (die Freiheit) to be knowable Necessity (erkennbare Notwendigkeit), not only assisted in formulating the Synergetic conception of Creative Order and Constructive Chaos, but also allowed to rethink Freedom as knowable Chance (erkennbare Chance), as to pave the way of achieving the measure of synthesis of Creative Order and Constructive Chaos [27].

In this manner, Dialectic of Freedom implies a transition from the dual opposition of Arbitrariness and Responsibility to that of Freedom as knowable Necessity and Responsibility as Knowable Chance.

Moreover, the measure of synthesis (considered as a counterbalancing point between Freedom and Responsibility) of Freedom as Knowable Necessity and Responsibility as knowable Chance is achieved through opting for a constructive way of social and cultural evolution, aimed at the absolute ideal common to all mankind.

Specific regulations on navigating social and cultural processes are determined by objective and subjective factors of option aimed not only at the absolute ideal common to all mankind, but also at relative individual ideals. Trends in social and cultural evolution are determined by conformity of alternative versions contained within the Thesaurus, to relative individual ideals shared by subjects of choice, because, in contradistinction to the Thesaurus whose contents are independent of subjects' choice, those ideals provide them with a chance to opt for the only alternative from multitudes, contained within the Thesaurus. Thus, the adequacy of opting for an alternative (constructive or destructive) way of social and cultural evolution depends on whether it is aimed at the absolute ideal common to all mankind or at anti-ideals, leading humanity to a social and cultural catastrophe [28].

Finding a solution to the problem of forming Humanity's capabilities of being incorporated into future Metagalactic space $^{8}$ assumes not so much acts of operating by mechanisms of reproducing human beings' mental activity as their qualitative transformations, determined by the Law of Selforganizing ideals [29]. Constructive mental activity giving mankind the greatest opportunity to live and chance to rise above any situation, is interpreted as a special progressive form of constructive creative activity whose criterion is the measure of synthesis of Freedom and Responsibility of global society members, aimed at fighting for their social and cultural counter-ideals [30].

The synergetic approach to the problem of reproduction of value orientations by global society members in the selforganizing Universe allows us not only to speculate on the Anthropic Principle ${ }^{9}$ as one of the most important instrumentals of achieving the measure of synthesis of Freedom and Responsibility in social and cultural activities [31], but also to develop the Fractal and Relativistic Model of the Universe [32], based on the Final Anthropic Principle ${ }^{10}$ contrived by John David Barrow (b. 1952), the English

8 Metagalactic Space implies a part of the observable Universe.

9 The Weak and Strong Anthropic Principles have been formulated by Brandon Carter (b.1942), the Australian theoretical physicist, [33] and grounded by John David Barrow and Frank Jennings Tipler [34], whereas the Participatory Anthropic Principle was postulated by John Archibald Wheeler (1911-2008), the American theoretical physicist [35], whereas the Final Anthropic Principle was formulated by John David Barrow [36].

10 The Final Anthropic Principle was devised by Frank Jennings Tipler and John David Barrow in their work 'The Anthropic Cosmological Principle' (1986) as a generalization of the Anthropic Principle: "Intelligent information processing must come into existence in the Universe, and once it comes into existence, will never die out" [40]. J. D. Barrow and F. J. Tipler considered physical statement to be closely connected with ethical values. Moreover, they contended that the Final Anthropic Principle limits the structure of the Universe [41]. One of such constraints is a big crunch, in which the Universe must end, resulting from dark energy based on observations of very distant supernovas. Besides, both scientists maintain that the Final Anthropic Principle was anticipated by the notions of teleology and Intelligent Design*. In particular, according to this Principle, inasmuch as the Universe does logically exist, it must contain Observers of its subsistence, for otherwise it would be logically senseless to state whether the Universe does or does not exist. The Universe obviously exists. And if the last

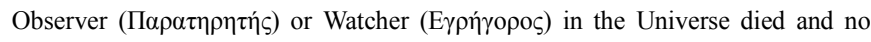
more Observers exist, it would mean that the Universe would no longer exist. However, inasmuch as it is inconsistent with the laws of physics that the Universe would stop existing, the Omega Point must sustain life forever [42].

*Intelligent Design implies a religious argument (or Watchmaker argument) for the existence of God presented by its proponents as an evidence-based scientific theory about life's origins, albeit discredited as pseudoscience. Proponents, however, contend that certain features of the Universe and of all things are best explained by an intelligent cause, not undirected processes such as natural selection [43]. 
cosmologist, theoretical physicist, and mathematician, and Frank Jennings Tipler (b. 1947), the American mathematical physicist and cosmologist, and interpreted as a testimony given to the inevitability of mankind's movement to the stage of Superhumanity (considered to be a self-organizing society of Homo Super).

The model in question demonstrates the interconnection of

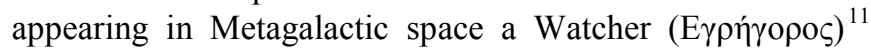
with the fundamental contradiction between Chaos and Order in nature and society manifested by the cardinal dual opposition of Chaos and Order which, in turn, was transformed in the course of social and cultural reproduction into the dual opposition of Freedom and Responsibility.

As the Cosmological Model developed by The founder of St. Petersburg Scientific School of Social Synergetics Vladimir P. Bransky (1930-2017), shows, the emergence of culture in Metagalactic space was followed by appearing

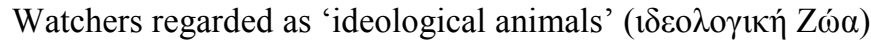
whose constructive mental activity was aimed at social, cultural, and religious ideals, while choosing their constructive ways of Self-determination [37].

The Emotional Model of Social and Cultural SelfOrganization developed from the Synergetic Historicism position as a panorama of permanently alternating social and cultural ideals, is focused on the pole of spiritual ideals and stipulates the measure of synthesis of social responsibility of global society members for products of their activities [38]. This very measure of synthesis is aimed at preventing the anthroposphere ${ }^{12}$ and local cultures from destroying ${ }^{13}$ in the wake of destructive innovations inspired by anti-ideals. In this manner, the tendency of prebiological development in the Cosmos ${ }^{14}$ results in the trial mental transformation of Homo Sapiens into Homo Faber and then, into Homo Super (that is to say, into human beings possessing superhuman mental capabilities). Such a transformation would assist not only in overcoming limits of evolution processes, imposed by natural laws, but also in neutralizing them by counterphenomena determined, in turn, by other objective laws.

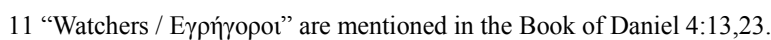

12 The anthroposphere (or technosphere) implies the part of environment and the material goods, made or modified by humans for use in human activities and associated with industrial metabolism*, as the industrial analogue of biomass [44].

*The term "metabolism" in its original biological context connotes the internal processes of a living organism. The organism ingests energy-rich, low-entropy materials to provide its own subsistence and reproduction. The process also involves excretion consisting of degraded, high-entropy materials. Both biological organisms and industrial activities are materials-processing systems driven by a flow of free energy, as well as both are examples of self-organizing dissipative systems in a stable state, from thermodynamic equilibrium. Thereby, the metabolism of industry is regarded as the whole integrated collection of physical processes converting raw materials, energy, and labour into finished products and wastes in a more or less steady- state condition. The human role in such processes is determined by two aspects such as labour input and consumer output.

13 The state of global thermodynamic equilibrium implies maximum entropy, disorder and randomness, tempting to assume that maximum order corresponds to minimum entropy [45].

14 The Cosmos, or the Universe, is regarded as a complex and orderly entity opposed to Chaos.
Thereby, products of synthesis of intercluding objective laws assist in generating qualitatively new transcendent meanings and values.

The problems of regression, resulting from growing entropy, which threaten Watchers not only with intruding on their existence but also with annihilating them, can be finally reduced to speculating on a fact that human beings (o $\alpha v \theta \rho \omega \pi \circ \varsigma \alpha \pi$ ó $\tau \eta \gamma \eta$ ) might be understood through the progress only. Such an approach is focused on studying a part of global society members in synthesis processes of Social, Cultural, Scientific and Technological Progress [39].

\section{Theoretical Prerequisites for Synthesis of Social, Cultural, Scientific and Technological Progress}

The synthesis of Social, Cultural, Scientific and Technological Progress was initiated by the Prigogine ${ }^{15}$ Theorem of the thermodynamics of non-equilibrium processes. ${ }^{16}$ This theorem contradicting the Second Law of thermodynamics ${ }^{17}$, was anticipated by Sergei Podolinsky (1850-1891), the Ukrainian physicist and pioneer of ecological economics, who was aimed at reconciling social thought and the Second Law of thermodynamics by synthesizing the approaches of Karl Marx (1818-1883), Charles Darwin (1809-1882), and Nicolas Leonard Sadi Carnot (1796-1832). Thereby, in 1880, he postulated the rule stating that 'Homo Faber' (as self-expressing subjects) due to their constructive mental activities, were invested with function of accumulating and transforming solar energy on the Earth's surface as to provide humanity with conditions required for human survival as well as to resist the dissipation of energy and the minimization of a growth of entropy ${ }^{18}[46]$. This, so-called "Podolinsky's Rule" marking

15 Viscount Ilya R. Prigogine (1917-2003), the Russian-born Belgian physical chemist and Noble Laureate, was noted for his definition of dissipative structures and their role in thermodynamic systems far from equilibrium, as well as on his work on complex systems and irreversibility. He discovered that importation and dissipation of energy into chemical systems could reverse the maximization of entropy rule, imposed by the Second Law of thermodynamics [51]. Dissipative structure theory led to pioneering research in self-organizing systems, as well as in philosophical inquiries into the formation of complexity of biological entities and the quest for a creative and irreversible role of time in the natural sciences [52].

Prigogine's formal concept of self-organization was used as a complementary bridge between General Systems Theory and thermodynamics [53].

16 According to the Prigogine Theorem, the minimum level of producing entropy in a system, under conditions preventing the attainment of the equilibrium state, corresponds to the steady state of that system. If there no such hindrances, the production of entropy reaches its absolute minimum - zero.

17 The Second Law of thermodynamics states that the total entropy of an isolated system always increases over time. However, it remains constant in ideal cases where the system is in a steady state or undergoing a reversible process. The increase in entropy accounts for the irreversibility of natural processes, and the asymmetry between future and past [54].

18 Entropy is a quantitative measure of what the Second Law of thermodynamics describes, to wit, the spreading of energy until it is evenly spread. So then, informational entropy is a measure of information communicated by systems, being affected by data noise, whereas thermodynamic entropy (as part of the 
a qualitatively new stage of synthesis of Social, Cultural, Scientific and Technological Progress, assisted in balancing the Second Law of thermodynamics considered to be the law of common equalization. This law was understood by Pavel Florensky (1882-1937), the Russian Orthodox theologian, philosopher, mathematician, and physicist, as the law of Chaos in all the Universe, according to which negentropy ${ }^{19}$ (as Logos) resists entropy. In this way, culture was thought of by Pavel Florensky not only as conscious fight against world equalization, but also as a life condition, preventing from equating process in the Universe and assisting in increasing a potential difference, in contradistinction to an equality (that is to say, to death). Pavel Florensky regarded culture as the target and interrelated system for reproducing spiritual values as a subject of faith separated from any religion.

Pavel Florensky regarded the real existence of the sphere of the Earth incorporated into humans' mental activities as 'Pneumatosphere (that is to say, a sphere of humans mental energy), having made a significant contribution to Vladimir Vernadsky's concept of Noosphere ${ }^{20}$, [47] by enriching it with his doctrine of Pneumatosphere as the spiritual sphere of Humanity [48].

The noosphere's concept as the scientific basis for Saving the Planet (as an Appeal to the Citizens of the Earth) originated in Sorbonna lectures of Vladimir Vernadsky (1863-1945), the Russian and Soviet mineralogist and geochemist, titled 'La Géochimie' [49] in 1924. However, Vernadsky adopted the term 'Noosphere' [50] not earlier than in 1927 when the work by Edouard Louis Emmanuel Julien Le Roy (1870-1954), the French mathematician and philosopher, 'Les Origines humaines et 1 'evolution de 1'intelligence' / The Human Origins and Evolution of Mind' was published, where the notions of Biosphere ${ }^{21}$ and

science of heat energy) is a measure of how energy is organized in a system of atoms or molecules. In this sense, entropy can be considered to be a measure of uncertainty.

19 Negentropy (negative entropy) is reverse entropy, and means things becoming more in order, implying organization structure and function opposite to randomness or chaos. The concept and term 'negative entropy' was introduced by Erwin Rudolf Josef Alexander Schrödinger (1887-1961), the Austrian physicist, who developed a number of fundamental results in the field of quantum theory, forming the basis for wave mechanics, in his work 'What is Life' (1954) [55]. The term 'negative entropy' was reduced to that of 'negentropy' by Leon Nicolas Brillouin (1889-1969), the French physicist, contributing to quantum mechanics [56]. In 2009, 'negentropy' of a dynamically ordered sub-system was redefined as the specific entropy deficit of the ordered sub-system relative to its surrounding chaos [57].

20 The term "Noosphere" (from 'vov / mind' and ' $\sigma \varphi \alpha \iota \rho \alpha$ / sphere') meaning the sphere of human thought [58], was first used in print by Edouard Louis Emmanuel Julien Le Roy [59]. However, it was probably coined in 1924 by his friend, Teilhard de Chardin, inspired by ideas of Edvard Suess (1831-1914), the Austrian geologist, who expounded this notion in his three-volume work "La Face de la Terre" (Das Antlitz der Erde / The Countenance of the Earth) (1885-1909) [60].

21 The term "Biosphere", connoting the entire earth as a single ecosystem, was coined in 1885 by Eduard Suess and popularized by hypothesizing that life was the geological force shaping the Earth. According to the First* and Second biogeochemical principles, the biosphere evolves in the direction of increasing stability and accelerating the biogenetic migration of atoms. Vernadsky contended that human thought appears in the noosphere as a lawful manifestation of biospheric evolution, which can only be separated from it in abstraction. His
Noosphere were explained [61].

Pierre Teilhard de Chardin (1881-1955), the Jesuit priest, geologist and paleontologist, regarded the noosphere from his Catholic mystic perspective, as the spiritual realm that would be achieved by Humanity through overcoming the material world and transferring from the biosphere into the Omega, identified with Christ, who has no higher stage [62]. This vitalist $^{22}$ idea of the Omega Point as a maximum level of complexity and consciousness originated in the dual character of matter and energy appearing at the atomic level [63]. The interior aspect of matter (of atoms) implied the constant presence of Omega from the very beginning of the Universe [64]. This Chardin's concept was the principle of the movement of Humanity towards the supermind in the course of evolution and beyond the evolutionary mechanisms [65]. The transcendental Omega-Point was thus regarded as a pure state of being without any material constituents [66].

Thomas Berry (1914-2009), the Catholic priest of the Passionist Order (Congregatio Passionis Jesu Christ), the cosmologist, geologist and cultural historian, followed Teilhard de Chardin's tradition, advocating 'ecospirituality'. Berry considered humans as a global and cosmic species collectively enacting spatio-temporal agency as a force powerful enough to induce radical biospheric changes. Thomas Berry believed that humanity is poised to play a new constructive role in synthesis of Social, Cultural, Scientific and Technological Progress as vital constituent of a larger cosmic community [67]. Berry considered the Cosmos to be a dynamic, unfolding drama, a cosmogenesis characterized by increasing complexity, consciousness, and cephalization (understood as development of the central nervous system), leading to large-brained humans (understood as 'ideological animals'). While Teilhard de Chardin sought a mystical synthesis of science and religion, Berry investigated in what way this synthesis could powerfully evoke constructive human changes. Nevertheless, both Teilhard and Berry regarded the Universe as a whole exhibiting a psychic-cumphysical character. However, Berry believed that in humans (as 'ideological animals'), consciousness has developed into complex forms of self-consciousness as reflective thought.

noosphere concept supposed that the reflective human mind would expand its control of the whole geological stratum, and that human beings-cum-watchers would spread throughout the Cosmos [72].

The concept initially defined by Suess as a particular envelope of the terrestrial crust, a layer permeated by life, was rethought by Teilhard de Chardin as the actual layer of vitalized substance, enveloping the earth. Vladimir Vernadsky, in turn, developed this idea by adding that not only Man exists within the biosphere and in no way can exist beyond it, but also the biosphere itself, all terrestrial plants and animals are interconnected with one another through competition, nutrition, predation, parasitism, and decay, and with non-biotic solar, geological, hydrological, and atmospheric environment through photosynthesis respiration and transportation [73].

*The First Law of thermodynamics providing the basic definition of internal energy, associated with all thermodynamic systems, states the rule of conservation of energy [74].

22 Vitalism is the belief that living organisms are fundamentally different from non-living entities, for they contain some non-physical element or are governed by different principles than inanimate things are. This element is called the 'vital spark', 'energy' or 'elan vital' identified with the soul. 
Such a development was understood by Berry to be an inherent feature and tendency towards increasing cephalization [68]. Following Teilhard de Chardin, Thomas Berry postulated the law of complexification of consciousness, according to which the whole process of synthesis of Social, Cultural, Scientific and Technological Progress would provide Humanity with complexifying and deepening intelligence and emerging a radically new and transformative mindsphere (that is to say, the noosphere, or sphere of intellect), relevant to the future well-being on the Earth. The noosphere would thus be manifested by an additional thinking layer of the Earth system generated by human mental activity and its products.

Developing Teilhard's concept of hominization, Berry investigated the way in which human thought transforms all previously existing practice and functions of the Earth. Thereby, Berry's noosphere superposes on the biosphere as an agent of planetary transformation resulting in greater hominization. Human decision-making, akin to natural selection's transformation of the biosphere, has hominized the natural selection process of the planet as a whole. Therefore, the noosphere would reshape the biosphere to such an extent that human beings would ultimately be transformed into Homo Super [69]. And moreover, Cosmic evolution would be characterized by the leading role of humanity, marking the evolutionary convergence of mind through synthesis of Social, Cultural, Scientific and Technological Progress, inevitably inducing the transformation of all Humanity into a global Supermind [70]. This concept of a global Supermind anticipated the Synergetic Historicism conception of Homo Sapiens being transformed into Homo Faber, and then, into Homo Super (Superhumanity) [71].

In contrast to Teilhard de Chardin's view on the noosphere from the Omega-Point's perspective, Vladimir Vernadsky, a Cosmic realist, considered the noosphere as the part of the biosphere, physically transformed by human activities [75]. Vernadsky strongly believed that evolution as an inevitable and progressive advance to a better future of Humanity can assist human intelligence in eliminating negative side-effects caused by the expansion of the noosphere. The noosphere was thus thought of by Vernadsky as the last of many stages in the evolution of the biosphere in geological history. "Now we live in the period of a new geological evolutionary change in the biosphere. - He wrote. - We are entering the noosphere. This new elemental geological process takes place at a stormy time, in the epoch of a destructive world war. But the important fact is that our democratic ideals are in tune with the elemental geological processes, with the natural laws and with the noosphere" [76]. Thereby, obvious parallels may be observed between Vernadsky's view on human activities, transforming the biosphere into noosphere, and the current view that human activities changing the Earth System, have initiated a new geological epoch. Vernadsky's idea of humanity's impact on the biosphere could be easily applied to any modern account of disrupting biogeochemical cycles.
Vernadsky's noosphere concept, differing from Teilhard's and Berry's, explicitly entailed not only human transformation of the environment, but also an idea that human knowledge possesses the potential for longer-term sustainable planetary management. In contradistinction to Teilhard's and Berry's mindsphere, Vernadsky's noosphere remained within the evolving material world and was no means considered to be a spiritual layer only. Nevertheless, Teilhard's and Berry's mystical as well as Vernadsky's materialist conceptions of noosphere were both products of evolutionary thinking which regarded civilized Man emerging in the Universe not as a Watcher but rather as a geological force developing over time. This evolutionary unfolding could be regarded as generally Lamarckian ${ }^{23}$ in the sense that the noosphere progressively develops as a higher stage of the human-directed evolving biosphere. As human knowledge of the cosmos increases, the noosphere incorporates new facts concerning the cosmos itself and its self-organization, allowing the mindsphere to become a Microcosm of the Macrocosm, both a mirror of the Cosmos as well as its directive agency, according to the Principle "Ev

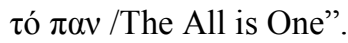

As Teilhard de Chardin proclaimed, the humans hold evolution in their hands, being responsible for its past and future. In this sense, Humanity is in no way the navel of the Universe but rather the arrow, pointing the path to the final unification of the world.

In contradistiction to Vernadsky's concept of the noosphere as the inevitable and progressive evolution of the biosphere, the Anthropocene ${ }^{24}$ concept rejected any advance to a higher stage [77]. Radically distinctive ways in which Teilhard, Berry, Vernadsky, and the advocates of the Anthropocene concept treated the notions of biosphere and noosphere, depended on their conceptualizations of what the Earth is and how this planet moves.

The similarities in Chardin's, Berry's and Vernadsky's concepts were that evolution was regarded by them as a process aimed at ever-higher levels of cephalization, culminating in the incredible growth of the human brain and consciousness, leading to the transformation of Humanity into Superhumanity and thus anticipating the Synergetic Historicism conception of Superhumanity [78].

In contrast to Chardin's, Berry's and Vernadsky's idea of Humanity playing the constructive role of mind and consciousness of the Cosmos, Pavel Florensky supposed that humans lead their planet to a critical threshold of the unbalance, and exceeding this threshold can result not only in

23 Jean-Baptist Lamarck (1744-1829), the French biologist, incorporated the action of soft inheritance into his evolutionary theory as a supplement to his concept of orthogenesis, a drive towards complexity. The theory was opposed to Darwinian, since it represented a false picture of the history of biology, as Lamarck did not originate the idea of soft inheritance known from the classical era onwards.

24 The Anthropocene concept could be regarded as a new anthropogenic rift in the natural history of the planet Earth rather than as the further development of an anthropocentric biosphere. The proponents of the Anthropocene concept considered Homo Faber as the power able to disturb the self-organizing natural cycles that govern the planet's trajectory [82]. 
corrupting their own spiritual values, but also in destroying earthly self-organizing mechanisms. Therefore Humanity should be aimed at opposing inertia of destroying spiritual ideals by improving a qualitatively condition of the thin layer of the planet called by Florensky "Pneumatosphere". The idea of spirituality, according to Florensky, must be incorporated into human life as the fundamental principle of Human Existence. Only by being aimed at the Absolute Ideal and values proclaimed by it, humanity could restore dynamic balance lost by the system of the Earth. Similarly, both Vernadsky's and Florensky's concepts can be considered as one of the special forms of the collective influence of humanity on harmonizing biosphere, noosphere, and pneumatosphere of the Earth achieved through the synthesis of the intellectual and spiritual development of Humanity [79].

Florensky's concept of culture as an instrument of Humanity's struggle against World Chaos by means of negentropy anticipated the so-called Law, postulated by Sergei Podolinsky (1850-1891) in his work, "Human Labour and Its Attitude to the Dissipation of Energy" [80], by grounding the process, counteracting dissipation of the Sun's energy on the Earth's surface by means of human constructive mental activities, aimed at being able to provide humanity with survival and obtaining the stage of Superhumanity [81].

Dynamic development of Scientific and Technological Progress resulted in the imminent transition from industrial to high technological society whose critical resources comprised information and technological innovations, assisting in the formation of new scientific models of the World.

The historical transformations in sciences were marked by the so-called Ilya Prigogine's ${ }^{25}$ Paradigm $^{26}$ of SelfOrganization focused on the problem of relationships between human and physical realities [83]. Prigogine's Paradigm was not only focused on aspects of reality typical of the modern stage of social transformations (in a dehumanized society) such as non-stability, randomness, non-equilibrium, non-linearity, but also assisted in rethinking the notion of time as the constituent of the synthesis of Social, Cultural, Scientific and Technological Progress [84].

Investigating self-organizing processes in nature on the level of human individual and social consciousness, Prigogine has revealed that in far-from-equilibrium conditions, transformation from disorder (or thermal chaos) into order may also take place. And moreover, new dynamic states of matter may reflect the interaction between a given

25 Ilya R. Prigogine (1917-2003), the physical chemist of Russian origin and Nobel laureate, was noted for his work on dissipative structures, complex systems, and irreversibility.

26 Prigogine's Paradigm of self-organization connected with natural historical reality, acknowledges the necessity of understanding it as a whole, including humanity, and is aimed at explaining his non-classical conception of science. It deals with strong non-equilibrium and self-complication and forms the basis for cosmology [93]. Prigogine's concept of self-organization might be considered natural-cum-historical due to interrelations between each natural science and the technological conquest of nature [94]. system and its surroundings. These new systems were defined by him as dissipative structures ${ }^{27}$ [85].

According to Prigogine, increasing entropy corresponds to the spontaneous evolution of the system. Entropy thus becomes indicator of evolution or "Time's Arrow" as Sir Arthur Stanley Eddington (1882-1944), the English astronomer, physicist, and mathematician, aptly called it. For all isolated systems, the future is aimed at increasing entropy [86]. The concept, declaring that no system could be better 'isolated' than the Universe as a whole [87], became the basis for the cosmological formulation of the two laws of thermodynamics by Rudolf Julius Emanuel Clausius (18221888), the German physicist and mathematician, one of the founders of the science of thermodynamics. In his work "On the Moving Force of Heat and the Law of Heat Which May Be Deduced Therefrom" [88], he stated the basic ideas of the Second Law of thermodynamics. Then, in 1865., he introduced the concept of entropy. Clausius concluded that the entropy of the Universe tends to a maximum: "Die Energy, der Welt ist konstant. Die Entropie der Welt strebt einem Maximum zu"28 [89].

As anthropology witnesses, conceptions of time in cultures of local civilizations were different. For instance, the culture of Judaism was characterized by cyclic (of the eternal return) time, whereas the culture of Christianity, in turn, by linear (historical) time [90]. Besides, the stationariness in time was typical of all archaic local cultures.

Though Sir Isaac Newton (1642-1726), the English mathematician, astronomer and natural philosopher, who devised Clockwork Universe Model, stated that the total momentum of the Universe is conserved, interactions redistribute the momentum but the total never changes. In this model, God only started the clock (as initial cause), then it runs by itself for the rest of time. ${ }^{29}$ In this way, Newton's Clockwork Universe Model regarded time as an appendage devoid of significance, whereas any moment of time in the present, past or future was not distinguished from another [91].

27 Prigogine's Synergetics is based on the technological subordination of nature, whereas his synergistic method originates in theoretical investigating automatic chemical oscillations of Belousov-Zhabotinsky* reaction, considered to be a classical example of non-equilibrium thermodynamics, resulting in establishing a non-linear chemical oscillator. This natural-cum-historical character of the synergistic Prigogine's theories resulted in such physical and mathematical concepts which allowed to regard chaos, reality, and linear historical time as microscopic entropy' inner- time operator) as well as to redefine the Second Law of thermodynamics as the fundamental principle of dynamics [95].

*Boris P. Belousov (1893-1970), the Soviet chemist and biochemist, discovered the Belousov-Zhabotinsky reaction in the early 1950s. His work initiated the field of modern non-linear chemical dynamics.

Anatol M. Zhabotinsky (1938-2008), the Soviet biochemist, in the early 1960s postulated a theory of the chemical clock known as Belousov-Zhabotinsky reaction and published the results of his experiments on chemical wave propagation and pattern formation in non-uniform media.

28 "Energy in the World is constant. Entropy of the World strives for maximum" (Increasing entropy is no synonymous with loss but implies the natural processes within the system. Those processes ultimately lead the system to thermodynamic equilibrium, corresponding to the state of maximum entropy).

29 Sir Isaac Newton insisted that divine intervention would eventually be required to reform the system, due to the slow growth of instabilities. 
Time's Arrow of Arthur Eddington evidenced irreversibility of the train of events in the Universe as to prevent from continually increasing entropy ${ }^{30}$ [92]. Ilya Prigogine, however, not only proved that Time's Arrow is manifested only if a system stochastically ${ }^{31}$ behaves, but also demonstrated numerous examples of irreversibility such as radioactive decay, solar radiation, diffusion, and evolution of life. And moreover, Prigogine proved that determinism loses its explanatory power due to irreversibility and instability. The time's problem is interconnected with the problem of sense of social history and of the meaning-of-individual existence, on the one hand, and that of achieving a measure of synthesis of Freedom and Responsibility, on the other. Thereby, the human history finds its sense in the world which is not subjected to laws of determinism and in which unpredictability becomes a prerequisite for reproducing constructive innovations, aimed at social and cultural ideals.

Any human society (as a group of people sharing common ideals) functions on the verge of imbalance, determined by a possibility of maintaining life in open systems, exchanging energy, matter, and information with their surroundings. Therefore not all bifurcations result in generating new historical systems due to interrelations between specifics of social history and sequence of events whose microstructure is able to distinguish the past from the future, and whose idea is equated with that of bifurcation expressed by non-linear laws of evolution. And inasmuch as the specific nature of events is characterized by qualities of their predictability or unpredictability, since any event results from a constructive or destructive bifurcation, such bifurcations impart to events their constructive or destructive aspects [96].

\section{The Synergetic Approach to the Problem of the Meaning-of-Life}

The approach to the key-problem of the Meaning-of-life from the Synergetic Historicism viewpoint is characterized by its cognoscibility and high-quality inexhaustibility, manifested by the movement of Humanity to the Global Attractor. This Global Attractor is identified with the Absolute Ideal, which infinite multitudes of 'ideological

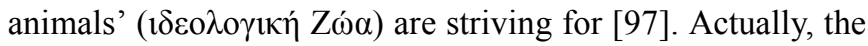
notion of the meaning-of-life is considered by teaching on ideals on the base of the analysis and synthesis of ideologies inherent to different societies and local civilizations [98]. Specifics of the methodological approach proposed by the authors, consist in taking into account a measure of synthesis of both Dramatic Optimism and 'Heroic Humanism'

30 The term 'Time's Arrow' was used by Sir Arthur Eddington in his work, 'The Nature of the Physical World', in order to express one-way property of time having no analogues in space. This 'Time's Arrow' is recognized not only by consciousness but also by human mind, understanding that a reversal of the arrow would render the external world nonsensical [108].

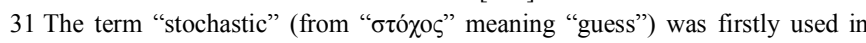
1953 by Joseph "Joe" Doob (1910-2004), the American mathematician, specializing in analysis and probability theory, in his work 'Stochastic Processes' [109]. concepts. The approach in question is aimed at constructing the Synergetic Model of Global Emotional Evolution of Humanity, which allows to eliminate the complicated ethical contradiction between inevitability of sacrifices made for realizing pragmatic aspects of relative individual ideals (determining the meaning-of-life of their followers) and requirements for rejecting those ideals as well as the onus put by them onto society members for their activities. The measure of synthesis concept is based on that of Heroic Humanism, advocating only those sacrifices which do not contradict ethical norms common to all mankind and oppose neither abstract nor extremist forms of Humanism [99].

Regarding the Synergetic Model of Global Progress [100] as one of constructive ways to the stage of Superhumanity, the authors give special attention to the cybernetic constituent of Synergetic Philosophy of History. This is explained by the relationship between Cybernetics (as a general theory of regulation) and the theory of social self-organization (as dissipative structures theory) [101]. And inasmuch as Cybernetics is regarded as an integral part of Synergetics, the Cybernetical Manifesto [102] was expediently enriched by Synergetic Manifesto [103].

The idea of the Global Attractor [104] distinguished by its rational aspects, is based on fundamental notions of Superselection and Utopian Circle. The growth of spatial and temporal scales of a simple selection results in accelerating the selection and grounding reasons for an incredible complication of a system in the shortest possible time [105]. The notion of Utopian Circle is cognate with that of the hermeneutical circle where the thinking of separate parts requires the thinking of the whole, whereas the thinking of the whole requires that of its parts. The idea of the Utopian Circle originates in social Utopias whose realization requires to equate an intersubjective social ideal with a relative individual ideal shared by every society member. Such an identity, however, is achieved through educating every member of a Utopian society to follow an intersubjective ideal, but this means that any Utopian society could have been built up only by its perfect citizens, though no known society possessed nearly perfect qualities for its citizens. Nevertheless, no known society possessed nearly perfect quality for its citizens. [106]. Howbeit, all the socialist and communist utopian systems, aimed at utopian ideals and based on egalitarian principles of equality in economics, government, and justice, were inevitably crashed in the wake of the contradictions between their real members' qualities and ideal society members' qualities. The contradiction, however, could be eliminated by the Law of Self-organizing social and cultural ideals. This Law provides the identity of the absolute ideal shared by all society members, with the absolute ideal shared by every stratified member, by means of copying parts and the whole (that is to say, ideals of this society and every its member), according to the principle of self-similarity of dissipative systems [107].

The specific nature of the Law of Self-organizing ideals is explained by specifics of forming and reproducing the ideal common to all mankind in the struggle between 
irreconcilable ideals, on the one hand, and of striving for ideological compromise, on the other. Ideological compromise is, however, unattainable without tolerance, aimed at neutralizing aggressiveness of intersubjective counter-ideals dominating in societies, whose synthesis with relative individual ideals of every society member assists in forming the absolute ideal common to all mankind in general and to every member of any society in particular. In this case, according to the principle of self-similarity, interreversible identity between local processes and their global analogue is obtained.

Both the formation and establishment of the Man's Absolute Ideal are oriented towards eliminating contradictions between relative individual ideals as to realize the Global Man Model on the base of the scientific approach to rethinking human beings as 'ideological animals'

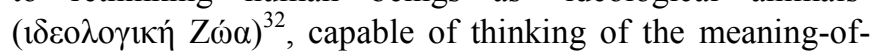
life and death [110].

The results of analyzing two alternative (constructive and destructive) tendencies of global development of humanity assisted in revealing alternative vectors of Transhumanism as follows:

(1) Firstly, the vector of ideology aimed at rejecting the traditional material aspect of transforming psychic information, which is realized in three main directions:

(2) of Theism distinguished by striving for replacing the problem of theodicy ${ }^{33}$ (related to that of cosmodicy and anthropodicy), not being rationally solved in conformity with a scientific Weltanschauung, with the problem of cliodicy ${ }^{34}[111]$;

(3) of Pantheism ${ }^{35}$ characterized by striving for grounding Panpsychism ${ }^{36}$ by means of Hylozoism, ${ }^{37}$ not

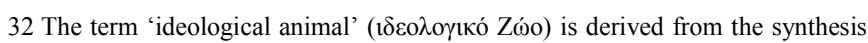
of notions 'political animal' ( 'universal animal' (allgemeines Thier) coined by Ludwig Andreas von Feuerbach

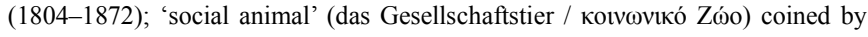
Karl Marx; and 'symbol-making animal' (animal symbolicum) coined by the Neo-Kantian Ernst Cassirer (1874-1945).

33 Theodicy is an attempt to answer the question of why a good God permits the manifestation of evil, thus resolving the issue of the problem of evil [112]. The term 'theodicy' was coined by Gottfried Wilhelm von Leibniz (1646-1716), the prominent German philosopher, in his attempt to justify God's existence in light of the apparent imperfections of the world [113].

34 Cliodicy is the problem of justifying the ways of history to man making the secularization of experience tolerable.

35 Pantheism is the doctrine identifying God with the Universe, on the one hand, and regarding the Universe as a manifestation of God, on the other.

36 Panpsychism (from ' $\pi \alpha v$ ' / 'all' and ' $\psi v x \eta$ ' / 'soul'), is the view that human consciousness, mind, or soul is a universal and primordial feature of all things.

37 Hylosoism (from ' $v \lambda \eta$ ' / 'matter') is the philosophical view on matter considered to be (in some sense) alive. The concept originated in the Milesian School* (the sixth century BC) of pre-Socratic philosophers. The term was introduced to English in 1678 by Ralph Cudworth (1617-1688), the English theologian and philosopher.

*The Milesian School of thought founded in the Ionian town of Miletus $(\mathrm{M} \backslash \lambda \eta \tau \mathrm{T} S)$ on the Aegean coast of Asia Minor, was represented by Thales of

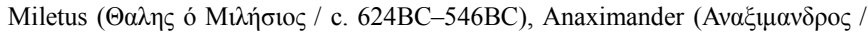

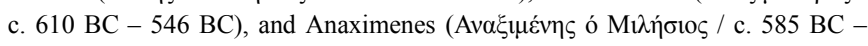
$528 \mathrm{BC}$ ), the Ancient Greek pre-Socratic philosophers, considered to be the first truly scientific philosophers who practiced material monism and thought of nature in terms of methodologically observable entities. conformed to modern science;

(4) of Deism ${ }^{38}$ oriented towards preventing from replacing an idea of pre-established harmony in nature with a counter-idea of self-organizing harmony.

(5) Secondly, the vector of de-ideologization aimed at rejecting the traditional biological aspect of informational processes, determined by human mental and psychic activities, as well as at the transition to the modelling of immortal cybernetic avatars as to replace human beings with products of genetic modification ${ }^{39}$ and nanorobotics. ${ }^{40}$

The criterion of a measure of constructiveness of Transhumanist ${ }^{41}$ vectors, according to the Synergetic Historicism conception, is the notion of Man distinguished by his dual nature whose synthesis of corporeal and spiritual aspects assists in directing the vector of reproducing the Global Model of Man from the pole of Antihumanism (oriented not only towards disharmonizing and disintegrating corporeal and spiritual aspects of human beings, but also towards their destroying) to the pole of Superhumanism. ${ }^{42}$

\section{Homo Faber as 'Ideological Animals': Their Place in Both Social History and the Globalization Process}

The secularization of the problem of the meaning-of-life resulted in accepting the selfless serving humanity progress, regarded as irreversible qualitative transformations of social reality according to the conception of progress ${ }^{43}$ by Robert

38 Deism is a system of philosophical beliefs that posits God's existence as the cause of all things, and admits its perfection, but rejects Divine revelation and government, while proclaiming the all-sufficiency of natural laws.

39 Genetic modificator, genetic manipulation, or genetic engineering, is the direct manipulation of an organism's genes using biotechnology. It is a set of technologies used to change the genetic make-up of cells, including the transfer of genes within and across species boundaries as to produce improved or novel organisms.

40 Nanorobotics (from ' $v \alpha v o \varsigma$ ' / dwarf), is an emerging technology field, creating robots whose components are at or near the scale of a nanometre (from ' $v \alpha v o \zeta$ '/ dwarf' and ' $\mu \varepsilon \tau \rho v^{\prime}$ ' / 'unit of measurement') written in scientific notation as $1 \times 10^{-9} \mathrm{~m}$ [114]. Nanorobotics refers to the nanotechnology engineering discipline of designing and building nanorobots, with devices ranging in size from 0.1-10 micrometers and constructed of nanoscale or molecular components [115].

41 Transhumanism is an international intellectual movement oriented towards transforming the human condition by developing and making widely available sophisticated technologies as to greatly enhance human intellect and physiology [120]. Therefore, human beings may eventually be able to transform themselves into transhuman beings (that is to say, into Homo Super representing Superhumanity, considered to be Posthumanity) [121].

42 Superhumanism, considered as the ability of human beings to go above and beyond the general expectations and realities of humankind, could be achieved through natural human abilities, self-development, self-actualization, and selfdetermination, resulting in creating the Ideal Man, in physical, mental and spiritual form considered as Homo Super, a representative of Superhumanity.

43 The idea of Progress was promoted by Robert Nisbet, who proclaimed in his work, 'The Quest for Community: A Study in the Ethics of Order and Freedom' (1953) that advances in technology, science, and social organization can provide humanity with improving the human condition, and that local civilizations are able to be improved in terms of their social, political, and economic structures, in the course of social and cultural evolution [122]. 
Alexander Nisbet (1913-1996), the American sociologist.

The conception of social and cultural progress regarded as the basis for grounding the meaning-of-life, and freed from a mystical approach, which declares that all social phenomena are subjected to social laws, was criticized due to the growth of global problems generated by Scientific and Technological Progress. Besides, Alarmists raised the exaggerated alarm about Scientific and Technological Progress, inevitably leading humanity to a global catastrophe [116].

As for the specific nature of Homo Faber and its interconnection with surroundings are revealed in culture in a form of values' constructive mental activity and its products, a solution to the problem of the meaning-of-life of Homo Faber demands that interrelationships between selforganization of Humanity on the whole and that of every creative society member in particular be taken into account [117]. The Synergetic approach oriented towards regarding

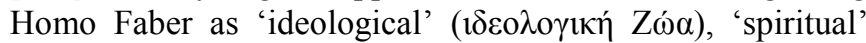

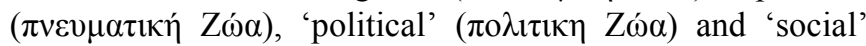

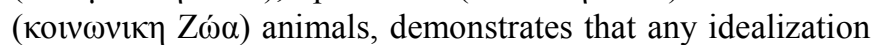
is inherent to human activities only, since the reproduction of spiritual ideals and values ${ }^{44}$ proclaimed by them, provides the dynamic synthesis of Scientific and Technological as well as Social and Cultural Progress on the way to the ideal common to all mankind. The reproduction of values without which the existence of Homo Faber is devoid of sense, becomes the meaning of individual subsistence of Homo Faber and the sense of social history [118].

According to the conception of Synergetic Historicism, Constructive Chaos (as a product of destroying ideals and values generated by them) is able to be self-organized by means of forming a creative thesaurus, containing a multitude of alternatives in every polyfurcation point. Thus, Homo Faber, aimed at opting for one of alternative ways of their self-development, function as the Creative Detector, whereas an ideal, directing their choice, functions as the Selector. The main threat preventing Humanity from approaching the Global Ideal, is the danger of returning to individual values devoid of their actuality that results in cyclicity of social transformations when life loses its meaning due to lacking in reproducing new values neither in long-term nor in short-term perspective.

Ideological fluctuations inherent to any developed society are generated by struggling secular and religious ideals, assisting in polarizing values and imparting to both social life and history a tragic shade. The fight of ideals results in their destruction, depriving adherents of those ideals of the meaning-of-life. The ideological struggle brings a society (oriented towards reproducing new ideals and new values) to an ideological crisis. Such a crisis, in turn, leads society members not only to revaluation and devaluation of spiritual and moral values, but also to the reproduction of utilitarian values in the wake of choosing a new dominant of consuming

44 Neither spiritual nor moral values are to be reduced to usefulness, existing both in nature and society, for their criteria are the necessaries of life, whereas the criterion of values, existing in society only, is an ideal [123]. utilitarian values [119]. Similarly, the spiritual crisis of any ideological society inevitably leads to de-ideologization of social life, resulting in global transition from the ideology of Transformism (oriented towards transforming reality) to that of Conformism (aimed at the adaptation to reality when society members reject to follow ideals and stop reproducing new spiritual values). However, inasmuch as the meaning-oflife in any consumer society is reduced to consumption of values once produced, a problem of producing new values would be not long in being actualized.

Any ideologized society is distinguished by a primacy of its members creativity, providing the dominance of spiritual values (serving as an objective) over utilitarian values (serving as a means of achieving this objective), whereas in any consumer society, spiritual values become secondary made to serve utilitarian values. Such a target inversion not only demonstrates that an objective as well as a means to an end have changed social roles with one another, but also became the main trend in thinking of mechanisms of transition from an ideologized creative society to deideologized consumer society. De-ideologization of any creative society inevitably results not only in substituting the striving after an ideal for the striving after a fashion, but also in radical transformations of social structures when consumption of utilitarian values becomes the new meaning of social life. Global history of artistic culture thus shows that, as a rule, life loses meaning only for those who fail in fighting for their ideals [124].

The social selection in social and cultural reproduction of values is determined by the Law of Self-organizing social and cultural ideals. The conception of Synergetic Historicism is thus oriented towards rethinking the synthesis of Social, Cultural, Scientific and Technological Progress as a potentially infinite movement to the Absolute Value which prevents Humanity from self-destruction. Synergetic Historicism grounds the root cause of destruction of human culture and a global humanitarian crisis by means of social and cultural dynamics of alternating ideological and consumer phases in any society development. According to the Law of Self-organizing social and cultural ideals, their periodic alternation in consequence of their degrading is a kind of empirical regularity, characterized by the successive alternation of a cult of creation by that of consumption in social history.

Therefore, the cognition of the Absolute (common to all mankind) Value might be provided by taking account of partial devaluation of new relative individual values and the periodic rejection of them on the base of the Law of Selforganizing social and cultural ideals.

Social and cultural ideals are a criterion of distinction between Homo Sapiens valuable-in himself in consumer societies and Homo Faber in creative societies. The transformation of Homo Faber from subjects (realizing themselves in culture) into Homo Super in the stage of Superhumanity results in forming the absolute, common to all mankind meaning-of-life. The periodic alternation of ideals reveals the dual sense of social history as well as the 
meaning of any individual's existence. Achieving the stage of Superhumanity through self-organization becomes complicated by the lack of synthesis of both creative and consumer societies, threatening with regression of Homo Faber to Homo Sapiens valuable in- themselves [125].

From the Synergetic Philosophy of History position, the problem of the correlation between absolute and relative values is solved on the base of the Law of Self-organizing social and cultural ideals, according to which the alternation of ideals results both in discarding all relative individual qualities of an ideal and in shaping invariant qualities common to all mankind [126]. The Absolute Ideal, generating the Absolute Value, becomes common to all mankind. Thereby, the meaning of Homo Faber' life and death as well as that of synthesis of Social, Cultural, Scientific and Technological Progress consists in serving an ideal common to all generations. And such an ideal is formed by mankind in the course of the irreconcilable ideological struggle.

Synergetic Historicism clearly demonstrates that achieving immortality might threaten Homo Faber with losing the meaning of their life. And, according to the synergistic treatment of death [127], the only death is able to provide both the alternation of generations and ideals shared by them by means of fighting ideals and revaluating values. Such an infinite fight of relative ideals and values generated by them assists Homo Faber in achieving not only a measure of synthesis of Chaos and Order as to impart to a system the maximum stability, but also a measure of synthesis of Freedom (as reflection of Chaos) and Responsibility (as reflection of Order) [128].

The conception of Synergetic Historicism assists in revealing the interrelationship between two cardinal dual oppositions characterizing dynamic processes of synthesis of Social, Cultural, Scientific and Technological Progress. The first of them is the dual opposition, whose one pole is aimed at obtaining the unity (a tendency to the globalization), whereas another is aimed at the diversity (a tendency to retain an identity). The second is the dual opposition, whose one pole is aimed at establishing a cult of Order and Responsibility (in Totalitarian societies), whereas another pole is aimed at establishing a cult of Chaos and Freedom (in Anarchist societies).

The approach to the search for a measure of synthesis between two poles of those oppositions from the Synergetic Historicism position takes into account functioning mechanisms of synthesis of social order and social chaos on the basis of reproducing a new social ideal which would play dominant role in social consciousness [129]. According to the Synergetic Historicism conception, the striving of humanity after Global Unity, on the one hand, and after Local Diversity, on the other, is explained by the Law of Selforganizing social and cultural ideals. Leaving out of account either interrelationship between the ideological chaos and the ideological order or the interrelations between the specific nature of globalization world and that of Homo Faber results in misrepresenting specific regularities of Homo Faber' nature modification, considered to be a key to the grounding of Homo Faber' root role in dynamic synthesis of Social, Cultural, Scientific and Technological Progress [130].

As the Synergetic Globalization theory asserts, the choice of alternative ways of transforming human nature is determined by terms of realizing the global ideal (that is to say, the Ideal of Homo Super). An image of Homo Super (Superior Man) would be accomplished by achieving the measure of synthesis of rights and responsibilities, through obtaining the absolute dominance of spiritual ideals and values over utilitarian ideals [131].

\section{Specifics of Reproducing the Genetic Code and Its Transformation into the Ideological Code}

Specifics of a new stage of synthesis of Social, Cultural, Scientific and Technological Progress consists in interrelated processes of reproducing the genetic code and its transformation into the ideological one [132]. It is known from molecular biology, the genetic code ${ }^{45}$ is highly similar among all organisms and can be expressed in a simple table with 64 entries. The Central Dogma of Molecular Biology (explaining the flow of genetic information within a biological system) first postulated in 1958 by Francis Harry Compton Crick (1916-2004), the British molecular biologist, biophysicist, and neuroscientist, stated that once 'information' has passed into protein it cannot get out again, to wit, the transfer of information from nucleic acid to nucleic acid, or from nucleic acid to protein may be possible, but transfer from protein to protein, or from protein to nucleic acid is impossible $^{46}[133]$.

Like a genome ${ }^{47}$, being an organism's complete set of DNA including all of its genes and containing all information needed to build and maintain that organism, an ideological genome contains a similar aggregate of inherited material in cells of Homo Faber' mind which contains all ideological information needed to his self-development and selfrealization in the stage of synthesis of Social, Cultural, Scientific and Technological Progress, as well as to his transformation into Homo Super [134].

Results of studying the dual character of human nature

45 The genetic code is the set of rules used by living cells to translate information encoded within genetic material (DNA or mRNA sequences) into proteins. Translation is accomplished by the ribosome linking amino acids in an order specified by messenger RNA (mRNA), using transfer RNA (tRNA) molecules to carry amino acids and to read the mRNA three nucleotides at a time [138].

46 The Central Dogma of Molecular Biology deals with the detailed residue- byresidue transfer of sequential information. It states that such information cannot be transferred back from protein to either protein or nucleic acid [139].

47 A genome is the genetic material of an organism consisting of DNA and including both the genes (the coding regions) and the non-coding DNA, as well as mitochondrial DNA and chloroplast DNA [140]. The term 'genome' ('gene' + 'chromosome') was coined in 1920 by Hans Karl Albert Winkler (1877-1945), the German botanist, in his work 'Verbreitung und Ursache der Parthenogenesis im Pflanzen- und Tierreiche' (Dissemination and Cause of Parthenogenesis in Plant- and Animal World) [141]. 
contributed to rethinking Homo Faber, on the one hand, as biological animals ( $\beta 10 \lambda \circ \gamma 1 \kappa \eta ́ ~ Z \omega ́ \alpha)$ distinguished by a mechanism of evolution in a form both of the genome and of the genetic code. This code continues to evolve after its initial creation so that the current code would maximize some fitness function [135], being stored on the two strands of a DNA molecules as a linear, non-overlapping sequence of the nitrogeneous bases, Adenine (A), Guanin (G), Cytosine (C), and Thiamine $(\mathrm{T})$, being the 'genetic alphabet' of four chemical letters (AGCT). The genetic information in mRNA is composed of an alternating sequence of the four bases, Adenine (A), Guanine (G), Cytosine (C), and Uracil (U). On the other hand, Homo Faber were thought of as 'ideological animals' ( $\delta \varepsilon \delta \lambda \sigma \gamma(\kappa \eta ́$ Z $\omega \alpha \alpha)$ distinguished by a mechanism of evolving ideologization in a form both of the ideological genome and of the ideological code, with its alphabet, containing the initial letters of the fundamental foundation of Social Synergetics theory; that is to say, the Law (L) of SelfOrganizing (SO) Ideals (I): LSOI. And if a biological genome is characterized by genes-and-chromosomes mechanism with such evolving constituents as genes and a genetic code, in an ideological genome, a function of evolving ideologization is delegated to this ideological code of non-genetic inheritance. The genetic code is transformed into the ideological code in the course of reproducing by Homo Faber their constructive mental activities by means of transmitting ideological information from generation to generation [136].

Self-realization and self-development of Homo Faber in the course of dynamical globalization progress are oriented towards reproducing social and cultural values. As far as Homo Faber model their activities in correspondence with their surroundings, the ideological genome provides the inheritance of the ideological code of reproducing ideological programs in every stage of developing local civilizations and their cultures. Like a biological genome ${ }^{48}$ an ideological genome functions as a selector choosing ideological information generally significant to be inherited. As social history shows, transitional periods of social and cultural development are marked by reproducing fundamental ideological programs as objective necessity, providing the stable reproduction of any social system [137]. Ideological programs formed by Homo Faber, objectively determined and measured, could be found in many historical sources.

Thereby, ideas of transforming a genetic code into an ideological one originate from the Judaist tradition of transmitting the individual code given by God (YHWH) to

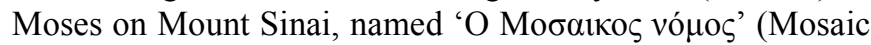
Law) or 'T $\alpha \delta \varepsilon \kappa \alpha \lambda$ ó $\gamma 1 \alpha$ ' (The Ten Commandments). ${ }^{49}$ This

48 The human genome is the complete set of nucleic acid sequences for humans, encoded as DNA within the 23 chromosome pairs in cell nuclei and in a small DM molecule found within individual mitochondria. Human genomes include both protein-coding DNA genes and non-coding DNA [142].

49 "And the Lord said unto Moses, Come up to me into the mount and be there: and I will give thee tables of stone, and a law, and commandments which I have written; that thou mayest teach them" (Exodus 24-12). constructive ideological code must be transmitted to Aaron Levite, the High Priest, the elder brother of Moses, and from him to his sons, Nadabh and Abhihu, the firstborn, being anointed (Exodus 28:1; Numbers 3:1-2), to sacrifice to God a red heifer without spot ( $\xi \alpha v \theta \eta v \delta \alpha \mu \alpha \lambda \imath v)$ in the wilderness of Sinai (Numbers 19:2-4). And as for as in this case the ideological genome failed to fulfil a task of a selector to choose and transmit individual ideological information to be inherited, the brothers distorted the ritual and died before the Lord when they offered strange fire (Numbers 3:2-4; 26:61). In this way, Nadabh and Abhihu, for offering strange fire, were devoured by fire from the Lord, since the priests were forbidden wine ${ }^{50}$ when they were to go into the tabernacle; and Aaron and his sons were forbidden to mourn for them (Leviticus 10:1-2).

The act of repealing the genetic code by Judeo-Christianity (to wit, the consanguinity prohibition) not only freed a son from his blood relationship (that is to say, from his genetic dependence on his father), instead giving to him God the Father common to all mankind, but also gifted him with the right to reproduce the new ideological code. Such an act resulted in the Second (the New) Exodus from the Old Testament World. This New Exodus was achieved through transforming the Act of Jesus' death on the cross into a mechanism of transforming death into a source of life [143].

The reproduction of ideological genomes in different stages of social and cultural evolution, considered from the Synergetic Historicism perspective as embryonic forms of self-organization in ancient social history, could be illustrated by following examples:

Firstly, The Instructions of Šuruppak (SU. KUP. RU), son of Ubara-Tutu, the last ruler of Sumer prior to the deluge, as a significant example of Sumerian wisdom literature (the cuneiform tablets from Abu Salabikh dated to the early third millennium BC) [144];

Secondly, Vedas ('knowledge'/ the second millennium BC) [145];

Thirdly, "The Loyalist Teachings, or The Loyalist Instructions" from a biographical stele at Abydos made in honour of Sehetepibre, a high government official and sealbearer who served under Senusret III (r. 1860BC- 1814BC). This inscription, emphasizing the virtues of loyalty to the ruling pharaoh and the responsibilities one must maintain for the sake of society [146], could be considered as the Egyptian ideological propaganda literature, aimed at extolling the virtues of the Pharaoh and reestablishing spiritual and moral values that ensure a stable society [147];

Fourthly, "The Admonitions of Ipuwer, or The Dialogue of Ipuwer and the Lord of All" (Papyrus Leiden 344 recto / The Dutch National Museum of Antiquities in Leiden, Netherlands) dated from the late Twelfth Dynasty of Egypt (c. 1991BC-1803BC) [148];

Fifthly, "The Code of Hammurabi" including "Lex

50 "Do not drink wine nor strong drink, thou, nor thy sons with thee, when ye go into the tabernacle of the congregation, lest ye die; it shall be a statute for ever throughout your generations" (Leviticus 10:9). 
Talionis" ('an eye for an eye, a tooth for a tooth'), the Babylonian code of law dated from c.1754 BC and consisting of 282 laws on a 2.25 meter stone stele [149];

Sixthly, Confucian 'Virtue Ethics' by the greatest Chinese thinker Confucius (Grand Master Kong / 551BC - 479BC) based on the Li-Principle [150] and oriented towards the dominant Taoist ideal, corresponding to the Golden Rule, proclaimed that first and foremost, what every society member does What not wish for himself, he does not do to others (to wit, never impose on others you would not choose for yourself) (Analects XV.24). Confucius' Virtue Ethics proclaimed the norms of proper social behaviour as taught by forefathers in order to promote commonly significant ideals of filial piety, brotherliness, righteousness, faith, and loyalty to the rulers [151];

Seventhly, one of the greatest commandments of the Old Testament proclaiming that, inasmuch as the Lord Israel's God is one Lord, Israelites should love the Lord their God with all their heart, and with all their soul, and with all their might (Deuteronomy 6:5);

And, finally, the Three Greatest Commandments of Jesus Christ as follows:

"You shall love the Lord your God with all your heart, with all your soul, and with all your mind" (Matthew 22:37; Mark 12:30);

"You shall love your neighbour as yourself" (Matthew 22:39; Mark 12:31);

"Love your enemies, do good to those who hate you..." (Luke 6:27).

In this way, the transmission of the right ideological code provided Humanity with the constructive path, aimed at self-reproduction and reproduction of social, cultural, and religious ideals in order to prevent from growing entropy, caused by reproducing anti-ideals and anti-values which lead humanity to fall into Chaos. The new stage of Superhumanity would be marked by achieving the measure of synthesis of social Freedom and ethical Responsibility of Homo Super for products of their mental activities. Similarly, polyfurcations, causing the emergence of new historical systems, with their new ideological programs, are initiated by Homo Faber, choosing their constructive way of self-determination.

\section{Conclusion}

The results of studying constructive and destructive ways of Global Development of Humanity allowed to draw conclusions of profound methodological significance to develop the theory of social self-organization and investigate specific regularities of social and cultural dynamics.

(I) The scientific theory of ideology as the teaching on ideals developed from the Synergetic Philosophy of History perspective, assists not only in avoiding the illegal identity of such fundamental philosophical notions as an objective truth and an intersubjective ideal, but also in revealing the interrelationship between the formation of the absolute truth common to all mankind in the wake of analysis and synthesis of relative individual truths, and the formation of the absolute ideal common to all mankind in the wake of analysis and synthesis of relative individual ideals.

(II) The Law of Self-organizing social, cultural, and religious ideals assists in overcoming cyclicity of the Global Utopian Circle (as a result of all failing Utopias) by the agency of forming an absolute ideal shared by every society member, analogous to the formation of the absolute ideal followed by the global society in accordance with the principle of self-similarity of dissipative systems.

(III) Synergetic Philosophy of History considers life in biological and sociological aspects as the synthesis of reversible and irreversible, recurrent and unique, stable and mutable transformations of matter, on the one hand, and a product of reproducing and consuming social and cultural values, on the other. And in both cases, life is treated as a synthesis of two or more interrelated opposite processes. The infringement of such a synthesis results in negating life and emerging self-destroying systems (that is to say, in order-to-chaos transition).

(IV) The synergetic approach to the history of humanity is oriented towards rethinking it as the alternation of ideological order and ideological chaos, whereas social and cultural experiences accumulated by humanity, as the alternation of social and cultural order and social and cultural chaos, according to the Law of Self-organizing ideals.

(V) According to the Synergetic Historicism conception, the way of Homo Faber to the Absolute Ideal as a material embodying of the Global Attractor, consists in potentially infinite order-to-chaos and chaos-toorder transitions.

The specific nature of order and chaos states is determined by reversible dual (constructive and destructive, negative and positive) nature characterized by four states of order and chaos:

The state of Constructive Order aimed at selfreproduction and reproduction of social and cultural ideals and constructive scientific and Technological innovations;

The state of Destructive Order aimed at selfdestruction and reproduction of destructive innovations, anti-ideals, and anti-values.

The state of Destructive Chaos aimed at destruction of the current state of destructive Order;

The state of Constructive Chaos aimed at the reproduction of the qualitatively new stage of Constructive Order.

(VI) The specific of the new stage of synthesis of Social, Cultural, Scientific and Technological Progress is explained by specific nature of two cardinal dual oppositions:

Firstly, of that whose pole is distinguished by a tendency towards total determinism of Homo Faber' 
activities, whereas its other pole - by a tendency towards total permissiveness;

Secondly, of that whose one pole is aimed at the striving of Homo Faber after global unity, whereas its other - at their striving after potentially infinite local diversity.

(VII) A new stage in developing globalization processes in the social and cultural area, marked by a tendency towards accumulating culture common to all mankind, actualized the problem of tolerance and readiness of local culture bearers to ideological and dogmatic compromises.

(VIII)Inasmuch as globalization progress is oriented towards reproducing values in accordance with the ideal common to all mankind, this ideal becomes a criterion of social and cultural values. The dual nature of ideals is explained by a dual opposition whose one pole is aimed at ideological compromise, whereas its other pole - at the ideological struggle depriving any counter-ideal of its right of being reproduced and its followers of the meaning-of-life which consists in serving such an ideal.

The approach to the study on Homo Faber' specific nature from the Synergetic Philosophy of History perspective consists in their rethinking as

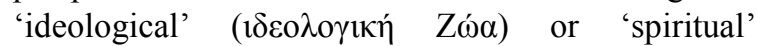
( $\pi v \varepsilon v \mu \alpha \tau \iota \kappa \eta ் ~ Z \omega ́ \alpha)$ animals whose mental activity is aimed at the ideal common to all humanity. This very ideal which assists in suppressing Homo Sapiens' biological instincts, also allows to transform Homo Sapiens into Homo Faber. If, however, those instincts deprive the ideal of its dominant role, such an ideological animal is instantaneously transformed into an 'instinctive (biological) animal', losing nature inherent in both Homo Sapiens and Homo Faber.

(IX) Results of the analysis of two alternative approaches to rethinking a role of Homo Faber in dynamic synthesis of Social, Cultural, Scientific and Technological Progress (in terms of those who regard Man as a destructive factor of the Universe evolution and reject human beings' specifics as 'ideological animals' following social, cultural, and religious ideals, on the one hand, and from the position of those who absolutize constructive aspects of humans aimed at subjecting Nature and Metagalaxy to their utilitarian ideals, on the other) allowed us to ground two alternative ways to the reproduction of Homo Faber' viability:

Firstly, a destructive way distinguished by the dominant of growth of complication over human beings' subjective capabilities of assimilating the new objective reality that results in decreasing a viability level, increasing disorder, and Homo Faber's self-destruction;

Secondly, a constructive way distinguished by human beings' forestalling capabilities of assimilating increasing complexity of the objective reality by the agency of its transformation into an object of thought as to provide the stable reproduction of Homo Faber' viability.

(X) The special significance of the approach to the problem of human immortality proposed from the Synergetic Historicism perspective, is explained by the fact that, in contradistinction to the problem of longevity, ${ }^{51}$ the former is regarded as the eschatological paradox, according to which, if Man becomes immortal his collective life could lose its meaning.

Endless attempts of humanity to achieve immortality were realized in both constructive and destructive ways. The constructive way of obtaining immortality was characterized by deification of rulers by means of immortalizing the memory of their deeds in artistic culture. So, first mastabas ('pr-djt' meaning 'house for eternity' in Ancient Egyptian), immortalizing the memory of Egyptian Pharaohs, began to be erected in pre-dynastic and early dynastic Egypt in $3150 \mathrm{BC}$, whereas first pyramids began to be constructed in $2667 \mathrm{BC}^{52}$

Moreover, the Akkadian Epic of Gilgamesh ${ }^{53}$ narrates a story of deeds of a historical ruler of the Sumerian city-state of Uruk, Gilgamesh (Bilgamesh / Giš. NEGA. MES / Archetypal / r. from 2800BC to 2500BC) who was posthumously deified as 'Shutar eli sharri / Surpassing All Other Kings'. As 'Sha naqba imuru' (He Who Saw the Deep) Gilgamesh, possessing superhuman strength and striving after immortality, went to the sage Utnapishtim, the only surviver of the Great Flood, to learn from him the secret of becoming immortal. Utnapishtim told Gilgamesh that, to become immortal he must defy sleep. Nevertheless, Gilgamesh failed to do this and fell asleep for seven days without waking. Thereby, Utnapishtim demonstrated to Gilgamesh the hopelessness of his quest for immortality, because creation itself contains the seed of death, making it inescapable. However, Utnapishtim comforted him telling that, even if he cannot obtain immortality, he can restore his youth using a plant with the power of rejuvenation. Having received this plant from Utnapishtim, Gilgamesh was soon deprived of it, while swimming, since a snake stole it (explaining

51 The problem of longevity deals with longevity being transformed from the greatest value of mankind into its greatest anti-value when society members ageing lose their capabilities of constructive mental activities.

52 Djoser (Tosorthros), the founder of the Third Dynasty of the Old Kingdom (r. c. $2686 \mathrm{BC}-2649 \mathrm{BC}$ ), commissioned in $2667 \mathrm{BC}$ the first step pyramid at Saqqara from Imhotep, his chief architect (and high priest of the sun god $\mathrm{Ra}$ ), who has accomplished it in 2648BC

53 The Epic of Gilgamesh written in cuineform in Akkadian in twelve clay tablets, was rediscovered in 1849 in the Royal Library of Ashurbanipal, the last great ruler of the Neo-Assyrian Empire (r. 668BC - 627BC). The Epic composed by a scribe named Sin-leqi-unninni between $1300 \mathrm{BC}$ and $1000 \mathrm{BC}$, was based on much older sources. 
why snakes are able to shed their skins).

The destructive way to find immortality may be illustrated by the example of Herostratus

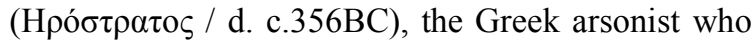
in $356 \mathrm{BC}$ sought notoriety by destroying (in act of arson) the Temple of Artemis. ${ }^{54}$ Herostratus' acts prompted the establishment of a Damnatio Memoriae law, forbidding anyone to mention his name.

(XI) The conception of Synergetic Historicism proclaims death as an inescapable attribute of the alternation of generations, without which the alternation of relative individual ideals also becomes impossible, wherefore the alternation of ideals results in forming and establishing the ideal common to all mankind. However, human immortality is to be achieved through historical traces (considered as invariant aspects of the absolute value common to all humanity), left by generations in the Global Attractor as the material embodying of the Absolute Ideal. Therefore, any negation of the objective character of the Global Attractor means nothing but the rejection both of ideology of imperishable values (not destroyed by time) and of the Dramatic Optimism conception inherent in any consistent scientific Weltanschauung. Thereby, immortality found in the course of potentially infinite movement to the Global Attractor, would be lost as those dynamic processes would be stopped. So then, according to the Synergetic Historicism conception, destructive processes of ageing humanity would be transformed into the constructive process of potentially infinite approaching the Global Attractor, within which neither ageing nor death would be possible. From a religious viewpoint, such processes of global deification may be identified with the 'Epiphany of

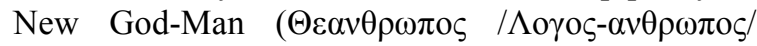
Deus Homo), capable of solving supernatural problems without violating objective determinism of both nature and society.

(XII) The option for a way of Harmonization of human nature, oriented towards overwhelming the striving for one-sided consummerism of utilitarian values, is explained by the constructive approach to the problem of regulating processes in question. A solution to this problem consists in the strong selection of society members as experts following the fundamental principles of Synergetic Historicism. This selection is needed, since any innovations generate constructive (to wit, the growth of harmonization) and destructive (to wit, the growth of disorder) factors, provoking new forms of antihumanism. Those new forms might be realized in

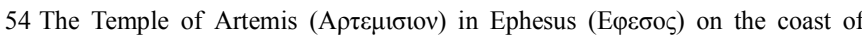
Ionia, was considered to be one of the Seven Wonders of the Ancient World. It was commissioned by Croesus (Kpoiøos / 595BC-546BC), the ruler of Lydia (from $560 \mathrm{BC}$ to $546 \mathrm{BC}$ ) around $550 \mathrm{BC}$ from the Cretan architects Chersiphron

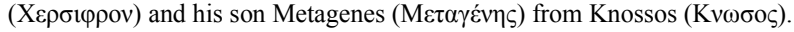

three main directions: firstly, in the direction of machinization distinguished by constructing robots not being controlled by humans; secondly, in the direction of biologization distinguished by communities of de-ideologized living creatures; and, finally, in the direction of mystification distinguished by coming to the earthly area phantoms from transcendent spaces. Harmonization, obtained on local levels, actualizes an issue of its globalization by achieving a measure (as a counterbalancing point between two poles of a dual opposition) of synthesis of Freedom of society members to choose alternative ways of Global development of Humanity, and their Responsibility for products of their constructive (or destructive) mental activities.

(XIII) The conception of Synergetic Historicism contributes to overwhelming the contradiction between the growth of human freedom, oriented towards regulating cosmic processes, and the principle of determinism, limiting freedom of choice by observing laws by means of their mutual compensation. Such a mutual compensation of laws may be illustrated by example of assimilating the $\operatorname{cosmos}^{55}$ by the agency of opposing the laws for reactive systems to the law of universal gravitation. Thereby, the profound study on specific nature of cosmic processes assists in forming qualitatively new methods of accelerating or slowing down planetary motions, bringing into action new planetoids and stars as well as of modifying star clusters and galaxies.

Nevertheless, according to the Law of Self-organizing Cosmic Matter, Homo Super' cosmic command, being subject to the Law of Self-organizing Ideals, is to be directed by the Absolute Ideal, for whose sake Superhumanity would intervene in Cosmic life. Therefore, self-organization of weak (in a cosmic sense) humanity would eventually result in its transformation into immeasurably more powerful (in both material and spiritual aspects) Superhumanity on the base of the principles of determinism and rationality. Besides, the Law of Self-organizing Cosmic Matter allows to overwhelm the Time Paradox, regarded by Ilya Prigogine as the simultaneous movement of Humanity to maximum Freedom and maximum Order. In this way, achieving harmony (that is to say, the measure of synthesis) between Chaos and Order, as well as between Freedom and Responsibility, can be realized by means of co-ordinating those opposite processes.

\section{References}

[1] Bransky, V. P., Mikailova, I. G. Self-Organization in Social and Cultural Dynamics of Reproducing Russian Mentality / V. P. Bransky, I. G. Mikailova // The World of Psychology. 2011. - Vol. 2. P. 51-60. (In Russian). P. 51-52.

55 The term 'Cosmos' is regarded as a whole harmonious and orderly system governed by natural laws, while by the term 'Universe' we mean all things that exist including time, space, matter, and the laws, governing them. 
[2] Synergetic Philosophy of History. Collective Monograph. V. P. Bransky, S. D. Pozharsky (eds.). - Ryazan': Copy-Print, 2009. (In Russian). P. 13-17.

[3] Bransky. V. P., Pozharsky, S. D., Mikailova, I. G., Busov, S. V., Zobova, M. R. Global Development from the Synergetic Philosophy of History Perspective / V. P. Bransky, S. D. Pozharsky, I. G. Mikailova, S. V. Busov, M. R. Zobova // Issues of Philosophy. - 2017. - Vol. 5. - P. 55-65. (In Russian). P. 56.

[4] Prigogine, I., Stengers, I. Order Out of Chaos. Man's Dialogue With Nature / I. Prigogine, I. Stengers. - New York: Bantam Books, 1984. P. 277.

[5] Bransky. V. P., Pozharsky, S. D., Mikailova, I. G., Busov, S. V., Zobova, M. R. Global Development from the Synergetic Philosophy of History Perspective / V. P. Bransky, S. D. Pozharsky, I. G. Mikailova, S. V. Busov, M. R. Zobova // Issues of Philosophy. - 2017. - Vol. 5. - P. 55-65. (In Russian). P. 57.

[6] Busov, S. V., Zobova, M. R. The Truth and Ideal Seen from the Problem of Russian Future Perspective / S. V. Busov, M. R. Zobova // The Future of Russia: Strategies of Philosophical Speculation. Collection of Papers. - SPb.: SPb State University Press, 2011. - P. 307-315. (In Russian).

[7] Mikailova, I. G. Art Modelling as a Factor in Fantastic Seeing Reality / I. G. Mikhailova. - SPb.: B\&K, 2005. (In Russian). P. 63-71.

[8] Bransky. V. P., Pozharsky, S. D., Mikailova, I. G., Busov, S. V., Zobova, M. R. Global Development from the Synergetic Philosophy of History Perspective / V. P. Bransky, S. D. Pozharsky, I. G. Mikailova, S. V. Busov, M. R. Zobova// Issues of Philosophy. - 2017. - Vol. 5. - P. 55-65. (In Russian). P. 57].

[9] Synergetic Philosophy of History. Collective Monograph. V. P. Bransky, S. D. Pozharsky (eds.). - Ryazan': Copy-Print, 2009. (In Russian). P. 93-113.

[10] Bransky, V. P., Mikailova, I. G., Zobova, M. R. The Problem of the Meaning-of-life: The Significance Common to All Mankind and of General Science. - SPb.: SPb State University, 2017. (In Russian). P. 18-19.

[11] Bransky. V. P., Pozharsky, S. D., Mikailova, I. G., Busov, S. V., Zobova, M. R. Global Development from the Synergetic Philosophy of History Perspective / V. P. Bransky, S. D. Pozharsky, I. G. Mikailova, S. V. Busov, M. R. Zobova // Issues of Philosophy. - 2017. - Vol. 5. - P. 55-65. (In Russian). P. 58.

[12] Global Future 2045. Convergent Technologies and Transhumanism Evolution. - M.: MBA, 2013. (In Russian).

[13] Bransky, V. P., Pozharsky, S. D., Mikailova, I. G., Busov, S. V., Zobova, M. R. Global Future, Transhumanism, and Synergetic Philosophy of History / V. P. Bransky, S. D. Pozharsky, I. G. Mikailova, S. V. Busov, M. R. Zobova // Philosophy of Science and Philosophy of Technique: History and Modernity. Collection of Scientific Transactions. - SPb.: LETI Press, 2015. (In Russian).

[14] Bransky, V. P. Synergetics and Cosmology (Philosophical Foundations of the Cosmological Model of the Universe / V. P. Bransky // Bulletin of St. Petersburg State University. Series 17. - 2014. - Issue 4. - P. 12-29. (In Russian). P. 18-21.
[15] Busov, S. V., Zobova, M. R. The Anthropic Principle from the Evolutionism and Synergetics Positions / S. V. Busov, M. R. Zobova. - SPb.: SPb National Research University of Information Technology, Mechanics, and Optics Press, 2016. (In Russian). P. 362-363.

[16] Bransky. V. P., Pozharsky, S. D., Mikailova, I. G., Busov, S. V., Zobova, M. R. Global Development from the Synergetic Philosophy of History Perspective / V. P. Bransky, S. D. Pozharsky, I. G. Mikailova, S. V. Busov, M. R. Zobova // Issues of Philosophy. - 2017. - Vol. 5. - P. 55-65. (In Russian). P. 58.

[17] Bransky. V. P., Pozharsky, S. D., Mikailova, I. G., Busov, S. V., Zobova, M. R. Global Development from the Synergetic Philosophy of History Perspective / V. P. Bransky, S. D. Pozharsky, I. G. Mikailova, S. V. Busov, M. R. Zobova // Issues of Philosophy. - 2017. - Vol. 5. - P. 55-65. (In Russian). P. 59.

[18] Bransky. V. P., Pozharsky, S. D., Mikailova, I. G., Busov, S. V., Zobova, M. R. Global Development from the Synergetic Philosophy of History Perspective / V. P. Bransky, S. D. Pozharsky, I. G. Mikailova, S. V. Busov, M. R. Zobova // Issues of Philosophy. - 2017. - Vol. 5. - P. 55-65. (In Russian). P. 59.

[19] Eden, A., Moor, J. Singularity Hypotheses: A Scientific and Philosophical Assessment / A. Eden, J. Moor. - Dordrecht: Springer Verlag, 2012. P. 1-2.

[20] Chalmers, D. The Singularity: A Philosophical Analysis / D. Chalmers // Journal of Consciousness Studies. - 2010. - Vol. 17. - Issue 9-10. - P. 7-65; Vinge, V. The Coming Technological Singularity: How to Survive in the Post-Human Era / V. Vinge // Vision-21 Symposium: Interdisciplinary Science and Engineering in the Era of Cyberspace. March 3031, 1993. - Washington: NASA Special Publications, 1993. P. 11-22;

[21] Desmond, A., Moore, J. Darwin / A. Desmond, J. Moore. London: Penguin Group, 1991. P. 263-274.

[22] Roughgarden, J. The Social Selection Alternative to Sexual Selection / J. Roughgarden // Philosophical Transactions of the Royal Society. B: Biological Sciences. - 2012. - Vol.367. - Issue 1600. - P. 2294-2303.

[23] Mikailova, I. G. A Book as Bearer of the Idea of Reproducing National, Devotional, and Civilization Identity By Means of an Example of Realizing the Peter I's of Russia Reforms / I. G. Mikailova // The World of Psychology. - 2014. - Vol. 4. - P. 33-46. (In Russian). P. 43-44.

[24] Mikailova, I. G. Dynamics of Reproducing the Russian Statehood and Its Interrelationship with Specifics of Russian Mentality / I. G. Mikailova // Russia: Tendencies and Perspectives of Development. In two parts. The Annual, Part One. - 2010. - Issue 5. - P. 454-458. (In Russian).

[25] Die List der Vernunft // Historisches Wörterbuch der Philosophie. - Frankfurt-am-Main: Suhrkamp, 1970. V, S. 343.

[26] Plantinga, A. God, Freedom, and Evil / A. Plantinga. - Grand Rapids: William B. Eerdmans Publishing Company, 1974.

[27] Mikailova, I. G. Social and Cultural Ideals and Global Artistic Culture. Vol. I. Social, Cultural, and Religious Ideals and Their Role in Dynamic Reproducing Human Civilization / I. G. Mikailova. - Saarbrücken: Palmarium Academic Publishing, 2016. (In Russian). P. 122. 
[28] The Cultural Life of Catastrophes and Crises. - Berlin: Walter de Gruyter, Ltd., 2012. P. 1-3.

[29] Zobova, M. R. Self-Organization of the Metagalaxy and the Emergence of Complex Dissipative Structures: Synergistic Analysis / M. R. Zobova // Scientific Journal of Volgograd State University. Series 7. Philosophe, Sociology, and Social Technologies. - 2016. - Vol. 4. - Issue 34. - P. 53-60. (In Russian). P. 54-55.

[30] Bransky, V. P., Mikailova, I. G. Self-Determining Subjects and Their Role in Dynamical Globalization Progress / V. P. Bransky, I. G. Mikailova // The World of Psychology. - 2018, - Vol. 1. - Issue 93. - P. 203-217. (In Russian). P. 204.

[31] Busov, S. V., Zobova, M. R. The Anthropic Principle and the Problem of Antinomies / S. V. Busov, M. R. Zobova // Perm' University Bulletin. Series Philosophy, Psychology, Sociology. - 2017. - Vol. 3. - P. 318-327. (In Russian).

[32] Bransky, V. P. Synergetics and Cosmology (Philosophical Foundations of the Cosmological Model of the Universe / V. P Bransky // Bulletin of St. Petersburg State University. Series 17. - 2014. - Issue 4. - P. 12-29. (In Russian). P. 18-21.

[33] Carter, B., McCrea, W. H. The Anthropic Principle and Its Implications for Biological Evolution / B. Carter, W. H. McCrea // Philosophical Transactions of the Royal Society. Series A: Mathematical, Physical and Engineering Sciences. 1983. - Vol. 310. - P. 347-363.

[34] Barrow, J. D., Tipler, F. J. The Anthropic Cosmological Principle / J. D. Barrow, F. J. Tipler. - New York: Oxford University Press, 1986. P. 288-457.

[35] Wheeler, J. A. At Home in the Universe / J. A. Wheeler. New York: American Institute of Physics Press, 1994. P. 272309.

[36] Barrow, J. D. Anthropic Definition / J. D. Barrow // Quarterly Journal of the Royal Astronomical Society. - 1997. - Vol. 24. - P. 146-153.

[37] Abecasis, G. R., Auton, A., Brooks, L. D. An Integrated Map of Genetic Variation From 1,092 Human Genoms / G. R. Abecasis, A. Auton, L. D. Brooks // Nature. - 2012. - Vol. 491. - Issue 7422. - P. 56-65.

[38] Mikailova, I. G. Social and Cultural Ideals and Global Artistic Culture. Vol. I. Social, Cultural, and Religious Ideals and Their Role in Dynamic Reproducing Human Civilization / I. G. Mikailova. - Saarbrücken: Palmarium Academic Publishing, 2016. (In Russian).

[39] Bransky, V. P., Mikailova, I. G. Self-Determining Subjects and Their Role in Dynamical Globalization Progress / V. P. Bransky, I. G. Mikailova // The World of Psychology. - 2018, - Vol. 1. - Issue 93. - P. 203-217. (In Russian). P. 204-205.

[40] Barrow, J. D., Tipler, F. J. The Anthropic Cosmological Principle / J. D. Barrow, F. J. Tipler. - New York: Oxford University Press, 1986. P. 23.

[41] Tipler, F. J. The Physics of Immortality: Modern Cosmology, God, and the Resurrection of the Dead / F. J. Tipler. - New York: Doubleday, 1994. P. 560.

[42] Tipler, F. The Omega Point as Eschaton: Answers to Pannenberg's Questions for Scientists / F. Tipler // Zygon. 1989. - Vol. 24. - Issue 2. - P. 217-253.
[43] Boundry, M., Blancke, S., Braeckman, J. Irreducible Incoherence and Intelligent Design: A Look Into the Conceptual Toolbox of a Pseudoscience / M. Boundry, S. Blancke, J. Braeckman // The Quarterly Review of Biology. 2010. - Vol. 85. - Issue 4. - P. 473-482.

[44] Ayres, R. Information, Entropy, and Progress. A New Evolutionary Paradigm / R. Ayres. - New York: AIP Press, 1994. P. 18

[45] Ayres, R. Information, Entropy, and Progress. A New Evolutionary Paradigm / R. Ayres. - New York: AIP Press, 1994. P. 12.

[46] Podolinsky, S. Human Labour and Dissipation of Energy / S. Podolinsky. - M.: Noosphere, 1991. (In Russian). P. 10.

[47] Vernadsky, V. P. Philosophical Thoughts of Naturalist / V. P. Vernadsky. - M.: Science, 1988. (In Russian). P. 69.

[48] Correspondence Between Vladimir I. Vernadsky and Pavel A. Florensky // The New World. - 1989. - Issue 2. - P. 194-303. (In Russian).

[49] Vernadsky, V. La Géochimie / V. Vernadsky. - Paris: Felix Alcan, 1924.

[50] Vernadsky, V. The Transition From the Biosphere to the Noosphere. Excerpts from Scientific Thought as a Planetary Phenomenon, 1938 / V. Vernadsky. - Washington 21st Century Science and Technology, 2012. P. 18.

[51] Macklem, P. T. Emergent Phenomena and the Secrets of Life / P. T. Macklem // Journal of Applied Physiology. - 2008. Vol. 104. - Issue 6. - P. 1844-1846.

[52] Keizer, J., Fox, R. F. Qualms Regarding the Range of Validity of the Glansdorf-Prigogine Criterion for Stability of NonEquilibrium States / J. Keizer, R. F. Fox // Proceedings of the National Academy of Sciences of the United States of America. - 1974. - Vol. 71. - Issue 1. - P. 192-196.

[53] Prigogine, I. Introduction to Thermodynamics of Irreversible Processes / I. Prigogine. - New York: Wiley Interscience, 1955. P. V-VI, 118-119, 133-134.

[54] Mahulikar, S. P., Herwig, H. Exact Thermodynamic Principles for Dynamic Order Existence and Evolution in Chaos / S. P. Mahulikar, H. Herwig // Chaos, Solitons, and Fractals. - 2009. - Vol. 41. - Issue 4. - P. 1939-1948.

[55] Schrödinger, E. What is Life - the Physical Aspect of the Living Cell / E. Schrödinger. - Cambridge, MA.: Cambridge University Press, 1944. P. 24-25.

[56] Brillouin, L. Negentropy Principle of Information / L. Brillouin // Journal of Applied Physics. - 1953. - Vol.24. Issue 9. - P. 1152-1163.

[57] Mahulikar, S. P., Herwig, H. Exact Thermodynamic Principles for Dynamic Order Existence and Evolution in Chaos / S. P. Mahulikar, H. Herwig // Chaos, Solitons, and Fractals. - 2009. - Vol. 41. - Issue 4. - P. 1939-1948.

[58] Levit, G. S. The Biosphere and the Noosphere Theories of V. I. Vernadsky and P. Teilhard de Chardin: A Methodological Essay / G. S. Levit // Archives Internationales d'Histoire des Sciences. - 2000. - Vol. 50. - Issue 144. - P. 160-177.

[59] Le Roy, E. Les origines humaines et 1'évolution de 1'intelligence. III. La Noosphère et l'Hominisation / E. Le Roy. - Paris: Boivin \& Cie, 1928. P. 37-57. P. 46. 
[60] Hamilton, C., Grinevald, J. Was the Anthropocene Anticipated? / C. Hamilton, J. Grinevald // The Anthropocene Review. - 2015. - Vol. 2. - Issue 1. - P. 1-14.; Suess, E. La face de la Terre (Das Antlitz der Erde). En cinq volumes / E. Suess. - Paris: Armand Colin et Cie, 1897-1918. IV, P. 1709_ 1724.

[61] Le Roy, E. Les origines humaines et 1'évolution de 1'intelligence. III. La Noosphère et l'Hominisation / E. Le Roy. - Paris: Boivin \& Cie, 1928. P. 37-57.

[62] Chardin, P. Teilhard de. Le Phénomène humain / P. Teilhard de Chardin. - Paris: Éditions du Seuil, 1955. P. 300.

[63] Olivier, G. Teilhard de Chardin et le Transformism / G. Olivier // Bulletins et Mémoires de la Société d'Anthropologie de Paris. - 1965. - T. 7. - Série XIe. - P. 351-359. P. 356-359.

[64] Chardin, P. Teilhard de. Le Phénomène humain / P. Teilhard de Chardin. - Paris: Éditions du Seuil, 1955. P. 269.

[65] Chardin, P. Teilhard de. La vision du passé / P. Teilhard de Chardin // 0euvres de Pierre Teilhard de Chardin, Vol. 3. Paris: Éditions du Seuil, 1957. III, P. 230-261.

[66] Chardin, P. Teilhard de. L'avenir de l'Homme / P. Teilhard de Chardin. - Paris: Éditions du Seuil, 1959. P. 163; Chardin, P. Teilhard de. L'Hominisation. Introduction à une étude scientifique du Phénomène humain / P.Teilhard de Chardin // 0euvres de Pierre Teilhard de Chardin, T. 3. - Paris: Éditions du Seuil, 1957. P. 75-111; Hamilton, C., Grinevald, J. Was the Anthropocene Anticipated? / C. Hamilton, J. Grinevald // The Anthropocene Review. - 2015. - Vol. 2. - Issue 1. - P. 114. P. 7-8.

[67] Sideris, L. H. Consecrating Science: Wonder, Knowledge, and the Natural World / L. H. Sideris. - Oakland: University of California Press, 2017. P. 116.

[68] Sideris, L. H. Consecrating Science: Wonder, Knowledge, and the Natural World / L. H. Sideris. - Oakland: University of California Press, 2017. P. 119.

[69] Sideris, L. H. Consecrating Science: Wonder, Knowledge, and the Natural World / L. H. Sideris. - Oakland: University of California Press, 2017. P. 121.

[70] Sideris, L. H. Consecrating Science: Wonder, Knowledge, and the Natural World / L. H. Sideris. - Oakland: University of California Press, 2017. P. 122.

[71] Mikailova, I. G. Social and Cultural Ideals and Global Artistic Culture. Vol. I. Social, Cultural, and Religious Ideals and Their Role in Dynamic Reproducing Human Civilization / I. G. Mikailova. - Saarbrücken: Palmarium Academic Publishing, 2016. (In Russian). P. 115-116.

[72] Vernadsky, V. P. Philosophical Thoughts of Naturalist / V. P. Vernadsky. - M.: Science, 1988. (In Russian). P. 130-132.

[73] Ayres, R. Information, Entropy, and Progress. A New Evolutionary Paradigm / R. Ayres. - New York: AIP Press, 1994. P. 18-19.

[74] Pokrovsky, V. N. Extended Thermodynamics in a DiscreteSystem Approach / V. N. Pokrovsky // European Journal of Physics. - 2005. - Vol. 26. - P. 769-781.

[75] Vernadsky, V. The Transition From the Biosphere to the Noosphere. Excerpts from Scientific Thought as a Planetary
Phenomenon, 1938 / V. Vernadsky. - Washington 21st Century Science and Technology, 2012. P. 27-28.

[76] Vernadsky, V. The Biosphere and the Noosphere / V. Vernadsky // American Scientist. - 1945. - Vol. 33. - Issue 1. - P. 1-12. P. 8-10.

[77] Hamilton, C., Grinevald, J. Was the Anthropocene Anticipated? / C. Hamilton, J. Grinevald // The Anthropocene Review. - 2015. - Vol. 2. - Issue 1. - P. 1-14. P. 9.

[78] Mikailova, I. G. Social and Cultural Ideals and Global Artistic Culture. Vol. I. Social, Cultural, and Religious Ideals and Their Role in Dynamic Reproducing Human Civilization / I. G. Mikailova. - Saarbrücken: Palmarium Academic Publishing, 2016. (In Russian). P. 115-116.

[79] Correspondence Between Vladimir I. Vernadsky and Pavel A. Florensky // The New World. - 1989. - Issue 2. - P. 194-303. (In Russian).

[80] Podolinsky, S. Human Labour and Dissipation of Energy / S. Podolinsky. - M.: Noosphere, 1991. (In Russian). P. 12-19.

[81] Bransky, V. P., Mikailova, I. G. Self-Determining Subjects and Their Role in Dynamical Globalization Progress / V. P. Bransky, I. G. Mikailova // The World of Psychology. - 2018, - Vol. 1. - Issue 93. - P. 203-217. (In Russian). P. 205-206.

[82] Hamilton, C., Grinevald, J. Was the Anthropocene Anticipated? / C. Hamilton, J. Grinevald // The Anthropocene Review. - 2015. - Vol. 2. - Issue 1. - P. 1-14. P. 9.

[83] Zwierlein, E. The Paradigm of Self-Organization and Its Philosophical Foundation / E. Zwierlein // Springer Series in Synergetics. - 1994. - Vol. 61. On Self-Organization. - P. 288-298; Näpinen, L. The Problem of the Relationship Between Human and Physical Realities in Ilya Prigogine's Paradigm of Self-Organization / L. Näpinen // Boston Studies on the History and Philosophy of Science. - Dordrecht: Kluwer Academic Publishers, 2001. - P. 151-164.

[84] Bransky, V. P., Mikailova, I. G. Self-Determining Subjects and Their Role in Dynamical Globalization Progress / V. P. Bransky, I. G. Mikailova // The World of Psychology. - 2018, - Vol. 1. - Issue 93. - P. 203-217. (In Russian). P. 206.

[85] Näpinen, L. The Problem of the Relationship Between Human and Physical Realities in Ilya Prigogine's Paradigm of SelfOrganization / L. Näpinen // Boston Studies on the History and Philosophy of Science. - Dordrecht: Kluwer Academic Publishers, 2001. - P. 151-164. P. 158.

[86] Prigogine, I., Stengers, I. Order Out of Chaos. Man's Dialogue With Nature / I. Prigogine, I. Stengers. - New York: Bantam Books, 1984. P. 119.

[87] Pokrovsky, V. N. Extended Thermodynamics in a DiscreteSystem Approach / V. N. Pokrovsky // European Journal of Physics. - 2005. - Vol. 26. - P. 769-781.

[88] Clausius, R. The Mechanical Theory of Heat - With Its Applications to the Steam-Engine and to Physical Properties of Bodies / R. Clausius. - London: John van Voorst, 1867. P. $14-69$.

[89] Pokrovsky, V. N. Extended Thermodynamics in a DiscreteSystem Approach / V. N. Pokrovsky // European Journal of Physics. - 2005. - Vol. 26. - P. 769-781. 
[90] Mikailova, I. G. Dynamics and Statics of Reception and Reflexion of Reproducing Religious Mentality / I. G. Mikailova // The World of Psychology. - 2013. - Vol. 1. - P. 155-167. (In Russian). P. 153.

[91] Eddington, A. S., Sir. The Nature of the Physical World / Sir A. S. Eddington. - London: Cambridge University Press, 1948 P. $20-25$.

[92] Eddington, A. S., Sir. The Nature of the Physical World / Sir A. S. Eddington. - London: Cambridge University Press, 1948. P. 37.

[93] Näpinen, L. The Problem of the Relationship Between Human and Physical Realities in Ilya Prigogine's Paradigm of SelfOrganization / L. Näpinen // Boston Studies on the History and Philosophy of Science. - Dordrecht: Kluwer Academic Publishers, 2001. - P. 151-164. P. 162-163.

[94] Contini, R. M. The Paradigm of the Complex Dynamic Systems and Sociological Analysis / R. M. Contini // Procedia - Social and Behavioural Sciences. - 2013. - Vol. 92. - P. 207-214.

[95] Näpinen, L. The Problem of the Relationship Between Human and Physical Realities in Ilya Prigogine's Paradigm of SelfOrganization / L. Näpinen // Boston Studies on the History and Philosophy of Science. - Dordrecht: Kluwer Academic Publishers, 2001. - P. 151-164. P. 160.

[96] Bransky, V. P., Mikailova, I. G. Self-Determining Subjects and Their Role in Dynamical Globalization Progress / V. P. Bransky, I. G. Mikailova // The World of Psychology. - 2018, - Vol. 1. - Issue 93. - P. 203-217. (In Russian). P. 206-207.

[97] Bransky, V. P., Pozharsky, S. D., Mikailova, I. G., Busov, S. V., Zobova, M. R. Global Future, Transhumanism, and Synergetic Philosophy of History / V. P. Bransky, S. D. Pozharsky, I. G. Mikailova, S. V. Busov, M. R. Zobova // Philosophy of Science and Philosophy of Technique: History and Modernity. Collection of Scientific Transactions. $-\mathrm{SPb}$.: LETI Press, 2015. (In Russian). P. 151.

[98] Mikailova, I. G. Memory as a Dynamic Factor of Reproducing Civilization Identity / I. G. Mikailova // The World of Psychology. - 2015. - Vol. 2. - P. 191-204. (In Russian). P. 191-204.

[99] Giustiniani, V. Homo, Humanus and the Meanings of Humanism / V. Guistiniani // Journal of the History of Ideas. 1985. - Vol. 46. - Issue 2. - P. 167-195.

[100] Synergetic Philosophy of History. Collective Monograph. V. P. Bransky, S. D. Pozharsky (eds.). - Ryazan': Copy-Print, 2009. (In Russian). P. 113-167.

[101] Bransky, V. P. Synergetics and Cosmology (Philosophical Foundations of the Cosmological Model of the Universe / V. P. Bransky // Bulletin of St. Petersburg State University. Series 17. - 2014. - Issue 4. - P. 12-29. (In Russian).

[102] Global Future 2045. Convergent Technologies and Transhumanism Evolution. - M.: MBA, 2013. (In Russian). P. 263-269.

[103] Mikailova, I. G. Social and Cultural Ideals and Global Artistic Culture. Vol. I. Social, Cultural, and Religious Ideals and Their Role in Dynamic Reproducing Human Civilization / I. G. Mikailova. - Saarbrücken: Palmarium Academic Publishing, 2016. (In Russian). P. 91-106.
[104] Bransky, V. P., Pozharsky, S. D. Globalization and Synergetic Historicism / V. P. Bransky, S. D. Pozharsky. - SPb.: Polytechnique, 2004. (In Russian). P. 33-36.

[105] Bransky, V. P. Synergetics and Cosmology (Philosophical Foundations of the Cosmological Model of the Universe / V. P. Bransky // Bulletin of St. Petersburg State University. Series 17. - 2014. - Issue 4. - P. 12-29. (In Russian). P. 22.

[106] Giroux, H. Utopian Thinking Under the Sign of Neoliberalism: Towards a Critical Pedagogy of Educated Hope / H. Giroux // Democracy and Nature. - 2003. - Vol. 9. - Issue 1. - P. 91105.

[107] Mandelbrot, B. The Fractal Geometry of Nature / B. Mandelbrot. - New York: W. H. Freeman and Company, 1977. P. 44-57.

[108] Eddington, A. S., Sir. The Nature of the Physical World / Sir A. S. Eddington. - London: Cambridge University Press, 1948. P. 35.

[109] Doob, J. L. Stochastic Processes / J. L. Doob. - Hoboken: John Wiley \& Sons, 1953. P. 37; Doob, J. L. Stochastic Process Measurability Conditions / J. L. Doob // Annales de 1'Institut Fourier. - 1975. - Vol. 25. - Issue 3-4. - P. 163-176.

[110] Bransky. V. P., Pozharsky, S. D., Mikailova, I. G., Busov, S. V., Zobova, M. R. Global Development from the Synergetic Philosophy of History Perspective / V. P. Bransky, S. D. Pozharsky, I. G. Mikailova, S. V. Busov, M. R. Zobova // Issues of Philosophy. - 2017. - Vol. 5. - P. 55-65. (In Russian). P. 60.

[111]Levine, G. Realism, Ethics and Secularism Essays on Victorian Literature and Science / G. Levine. - Cambridge, MA.: Cambridge University Press, 2008. P. 115.

[112] Devenish, Ph. Theodicy and Cosmodicy: The Contribution of Neoclassical Theism / Ph. Devenish // Journal of Empirical Theology. - 1992. - Vol. 4. - P. 5-23.

[113] Leibniz, G. W. Essais de Théodicée sur la bonté de Dieu, la liberté de l'homme et l'origine du mal / G. W. Leibniz.Amsterdam: David Mortier, Librairie, 1720.

[114] Sierra, D. P., Weir, N. A., Jones, J. F. A Review of Research in the Field of Nanorobotics / D. P. Sierra, N. A. Weir, J. F. Jones. - Oak Ridge: US Department of Energy, 2005. P. 1-50.

[115] Ignatyev, M. B. Necessary and Sufficient Conditions of Nanorobot Synthesis/ M. B. Ignatyev // Mathematical Reports. - 2010. - Vol. 82. - Issue 1. - P. 671-675.

[116] Mikailova, I. G. Self-Organizing Aesthetic Ideals. Their Part in the Aestheticization of Global Society in Terms of Synergetic Historicism / I. G. Mikailova. - Saarbrücken: LAP Lambert Academic Publishing, 2017. P. 3; Murray, D., Schwarz, J. Alarmism is an Infectious Disease / D. Murray, J. Schwarz // Society. - 2008. - Vol. 34.- Issue 4. - P. 35-40.

[117] Bransky, V. P., Mikailova, I. G. Self-Determining Subjects and Their Role in Dynamical Globalization Progress / V. P. Bransky, I. G. Mikailova // The World of Psychology. - 2018, - Vol. 1. - Issue 93. - P. 203-217. (In Russian). P. 208.

[118] Mikailova, I. G. Social and Cultural Ideals and Global Artistic Culture. Vol. I. Social, Cultural, and Religious Ideals and Their Role in Dynamic Reproducing Human Civilization / I. G. Mikailova. - Saarbrücken: Palmarium Academic Publishing, 2016. (In Russian). P. 114. 
[119] Bransky, V. P., Mikailova, I. G. Self-Determining Subjects and Their Role in Dynamical Globalization Progress / V. P. Bransky, I. G. Mikailova // The World of Psychology. - 2018, - Vol. 1. - Issue 93. - P. 203-217. (In Russian). P. 209.

[120] Bostrom, N. A History of Transhumanist Thought / N. Bostrom // Journal of Evolution and Technology. - 2005. Vol.14. - Issue 1. - P.1-30.

[121] Bostrom, N. Human Genetic Enhancements: A Transhumanist Perspective / N. Bostrom // Journal of Value Inquiry. - 2003. - Vol. 37. - Issue 4. - P. 493-506.

[122] Nisbet, R. History of the Idea of Progress / R. Nisbet. London: Transaction Publishers, 1994. P. 169-237.

[123] Mikailova, I. G. Social and Cultural Ideals and Global Artistic Culture. Vol. I. Social, Cultural, and Religious Ideals and Their Role in Dynamic Reproducing Human Civilization / I. G. Mikailova. - Saarbrücken: Palmarium Academic Publishing, 2016. (In Russian). P. 114.

[124] Bransky, V. P., Mikailova, I. G. Self-Determining Subjects and Their Role in Dynamical Globalization Progress / V. P. Bransky, I. G. Mikailova // The World of Psychology. - 2018, - Vol. 1. - Issue 93. - P. 203-217. (In Russian). P. 209.

[125] Mikailova, I. G. Human Value Orientations. Their Role in Dynamics of Reproducing Russian Civilization and Its Culture from the Synergetic Historicism Perspective / I. G. Mikailova. - Saarbrücken: LAP Lambert Academic Publishing, 2017. (In Russian). P. 74-78.

[126] Bransky, V. P., Mikailova, I. G. Self-Determining Subjects and Their Role in Dynamical Globalization Progress / V. P. Bransky, I. G. Mikailova // The World of Psychology. - 2018, - Vol. 1. - Issue 93. - P. 203-217. (In Russian). P. 210.

[127] Bransky, V. P., Mikailova, I. G., Zobova, M. R. The Problem of the Meaning-of-life: The Significance Common to All Mankind and of General Science. - SPb.: SPb State University, 2017. (In Russian). P. 14-15.

[128] Bransky. V. P., Pozharsky, S. D., Mikailova, I. G., Busov, S. V., Zobova, M. R. Global Development from the Synergetic Philosophy of History Perspective / V. P. Bransky, S. D. Pozharsky, I. G. Mikailova, S. V. Busov, M. R. Zobova // Issues of Philosophy. - 2017. - Vol. 5. - P. 55-65. (In Russian). P. 58-59.

[129] Bransky, V. P., Mikailova, I. G. Self-Determining Subjects and Their Role in Dynamical Globalization Progress / V. P. Bransky, I. G. Mikailova // The World of Psychology. - 2018, - Vol. 1. - Issue 93. - P. 203-217. (In Russian). P. 211.

[130] Bransky, V. P., Mikailova, I. G. Self-Organization in Social and Cultural Dynamics of Reproducing Russian Mentality / V. P. Bransky, I. G. Mikailova // The World of Psychology. 2011. - Vol. 2. P. 51-60. (In Russian). P. 54-55.

[131] Mikailova, I. G. Human Value Orientations. Their Role in Dynamics of Reproducing Russian Civilization and Its Culture from the Synergetic Historicism Perspective / I. G. Mikailova. - Saarbrücken: LAP Lambert Academic Publishing, 2017. (In Russian). P. 85-86.

[132] Mikailova, I. G. Ideals and Their Role in Social and Cultural Reproduction of Civilization from Synergetic Philosophy of History Positions / I. G. Mikailova. - SPb.: Aletheia, 2015. (In Russian). P. 611-613.
[133] Crick, F. H. C. On Protein Synthesis / F. H. C. Crick // Sanders, F. K. Symposis of the Society for Experimental Biology, XII: The Biological Replication of Macromolecules. - Cambridge, MA.: Cambridge University Press, 1958. - P. 138-163.

[134] Bransky, V. P., Mikailova, I. G. Self-Determining Subjects and Their Role in Dynamical Globalization Progress / V. P. Bransky, I. G. Mikailova // The World of Psychology. - 2018, - Vol. 1. - Issue 93. - P. 203-217. (In Russian). P. 212.

[135] Freeland, S. J., Knight, R. D., Landweber, L. F., Hurst, L. D. Early Fixation of an Optimal Genetic Code / S. J. Freeland, R. D. Knight, L. F. Landweber, L. D. Hurst // Molecular Biology and Evolution. - 2000. - Vol. 17. - Issue 4. - P. 511-518.

[136] Mikailova, I. G. Ideals and Their Role in Social and Cultural Reproduction of Civilization from Synergetic Philosophy of History Positions / I. G. Mikailova. - SPb.: Aletheia, 2015. (In Russian). P. 611-612; Mikailova, I. G. Human Value Orientations. Their Role in Dynamics of Reproducing Russian Civilization and Its Culture from the Synergetic Historicism Perspective / I. G. Mikailova. - Saarbrücken: LAP Lambert Academic Publishing, 2017. (In Russian). P. 222-223.

[137] Mikailova, I. G. Ideals and Their Role in Social and Cultural Reproduction of Civilization from Synergetic Philosophy of History Positions / I. G. Mikailova. - SPb.: Aletheia, 2015. (In Russian). P. 612-613.

[138] Shu, J-J. A New Integrated Symmetrical Table for Genetic Code / J-J. Shu // Biosystems. - 2017. -Vol. 151. - P. 21-26.

[139] Crick, F. Central Dogma of Molecular Biology / F. Crick // Nature. - 1970. - Vol. 227. - Issue 5258. - P. 561-563.

[140] Brosius, J. The Fragmental Gene / J. Brosius // Annals of the New York Academy of Sciences. - 2009. - Vol. 1178. - P. 186-193.

[141] Winkler, H. Verbreitung und Ursache der Parthenogenesis im Pflanzen- und Tierreiche / H. Winkler. - Jena: Verlag von Gustav Fischer, 1920. P. 165-166.

[142] Abecasis, G. R., Auton, A., Brooks, L. D. An Integrated Map of Genetic Variation From 1,092 Human Genoms / G. R. Abecasis, A. Auton, L. D. Brooks // Nature. - 2012. - Vol. 491. - Issue 7422. - P. 56-65.

[143] Mikailova, I. G. Dynamics and Statics of Reception and Reflexion of Reproducing Religious Mentality / I. G. Mikailova // The World of Psychology. - 2013. - Vol. 1. - P. 155-167. (In Russian). P. 159.

[144] Biggs, R. D. Inscriptions from Tell Abu Salabikh / R. D. Biggs. - Chicago: The University of Chicago Press, 1974. P. $30-32,57-61$.

[145] Basham, A. L. The Origins and Development of Classical Hinduism / A. L. Basham. - New York: Oxford University Press, 1989. P. 82-97.

[146] Parkinson, R. B. Poetry and Culture in Middle Kingdom Egypt: A Dark Side to Perfection / R. B. Parkinson. - London: Continuum, 2002. P. 313-319; Verhoeven, U. Von der Loyalistischen Lehre zur "Lehre des Kaisu" / U. Verhoeven // Zeitschrift für ägyptische Sprache und Altertumskunde. 2009. - Bd. 136. - S. 87-97. 
[147] Simpson, W. K. The Literature of Ancient Egypt: An Anthology of Stories, Instructions, and Poetry / W. K. Simpson. -New Haven: Yale University Press, 1972. P. 7-8; Global Future 2045. Convergent Technologies and Transhumanism Evolution. - M.: MBA, 2013. (In Russian). P. 83; Verhoeven, U. Von der Loyalistischen Lehre zur "Lehre des Kaisu" / U. Verhoeven // Zeitschrift für ägyptische Sprache und Altertumskunde. - 2009. - Bd. 136. - S. 87-97; Fischer-Elfert, H. Die Lehre eines Mannes für seinen Sohn: eine Etappe auf dem Gottesweg des loyalen und solidarischen Beamten der frühen 12. Dynastie. Ägyptologische Abhandlungen 60. - Wiesbaden: Harrosowitz, 1999. S. 418420 .

[148] Enmarch. R. The Reception of a Middle Egyptian Poem: The
Dialogue of Ipuwer and the Lord of All in the Ramesside Period and Beyond / R. Enmarch. - Bolton: Rutherford Press, 2011. P. 169-175; Gardiner, A. Egypt of the Pharaohs: an Introduction / A. Gardiner. - New York: Oxford University Press, 1961. P. 109-110; Grimal, N. A History of Ancient Egypt / N. Grimal. - Oxford: Blackwell Books, 1992. P. 138.

[149] Prince, J. D. Review: The Code of Hammurabi / J. D. Prince // The American Journal of Theology. - 1904. - Vol.8. - Issue 3. - P. 601-609.

[150] Virtue Ethics and Moral Education. - London: Routledge, 1999. P. 22.

[151] Chan, W. A Source Book in Chinese Philosophy / W. Chan.Princeton: Princeton University Press, 1963. P. 790. 